\title{
Development of ceramide and honey based biodegradable hydrogel dressing's materials for the application to burn skin
}

S. M. Masud Rana ( $\square$ ripon.quit@gmail.com )

Military Institute of Science and Technology https://orcid.org/0000-0003-4765-0273

Md. Ashrafuzzaman

Military Institute of Science and Technology

\section{Research Article}

Keywords: Ceramide, Hydrogel, Burn, Biomaterials

Posted Date: February 15th, 2021

DOI: https://doi.org/10.21203/rs.3.rs-183628/v1

License: (a) (i) This work is licensed under a Creative Commons Attribution 4.0 International License.

Read Full License 


\section{Abstract}

Ceramide is well known for its skin barrier function where hydrogel is an ideal one for wound healing, on the other hand honey is used for antibacterial activity and burn wound treatment from many years ago. So our aim to develop a ceramide loaded honey based hydrogel biomaterial for burn wound healing. The biomedical hydrogel biomaterial have been prepared by solution casting method. The developed Hydrogel membranes were characterized by using Fourier transform infrared spectroscopy (FT-IR), field emission scanning electron microscopy (FESEM) and UV-Vis Spectrophotometer. Besides that, swelling behavior in physiological solution, moisture retention capability, gel fraction, water vapor transmission rate (WVT), porosity and antimicrobial study were also evaluated. After all the hydrogel were evaluated for burn wound healing activity in mice model. Ceramide Hydrogel $\left(\mathrm{C}_{2}\right)$ \& Ceramide \& Honey Hydrogel $(\mathrm{CH})$ showed significant wound healing rate but only $\mathrm{CH}$ hydrogel showed significant antibacterial activity against Staphallycoccus aureus bacteria. Other physicochemical, swelling, WVT, porosity, gel fraction, weight loss, and FTIR, FESEM \& UV study was very satisfactory and all experimented data strongly support the use of the hydrogel membrane as a burn wound healing.

\section{Introduction}

Burns are a global public health problem, which causes disability \& mortality worldwide [1]. Due to fire induced burn, chemical burn, electric burn, radiation burn and incineration each year more than 3 lacs death reported by World Health Organization (WHO) [2, 3].The majority of the death are take place in middle and low income countries and almost half take place in South East Asia together with Bangladesh [4]. Burns injuries are caused by direct or indirect contact with heat, radiation, or chemical agents. In highincome countries, death rates due to burn injury have been decreasing, and the child deaths rate from burn injury is now more than seven times higher in middle and low income countries than in high income countries [5]. In Bangladesh, per year, per 1 lac populations overall mortality burn rate is 2.2 percent. The deaths are mainly accidental in nature and few are self-inflected burn (5\%) [6]. Due to burn injury skin loss its barrier functions to microorganisms leading to the potential risk of infection. Burn infection may delay healing, increase pain, increase chances of scarring and may even lead to death. Moist nature, high temperature, and nutrient rich environment of a burn wound it provide an ideal environment for growth of bacteria [7]. Owing to the wide area open burn surface being infected, curing of which takes long durations of dressings and leading to malformations patients face high morbidity than mortality. In burn injuries is protein denaturation and cell death (either by necrosis or apoptosis) are common denominator [8]. Some current therapy of the acutely burned patients are based on sufficient regeneration, quick wound debridement and closure, aid of post burn hypermetabolic response and control of infection. There are varieties of dressings available for treating both acute and chronicwounds. Some examples are solid wound dressings, gels, hydrogels, creams, ointments, and liquid wound washes. The types of materials used in dressing'smaterials include polyester, nylon, poly vinyl alcohol (PVA), alginate, collagen, poly ethylene glycol, and polylactic-co-glycolic acid. Typically these dressings contain silver, bismuth, chlorhexidine, polyhexamethylenebiguanide (PHMB) as a antimicrobial (e.g., bacitracin). According to 
Food and Drug Administration (FDA) wound dressings contain drugs such as silver, bismuth, chlorhexidineincluding certain risks of use and potential risk mitigation measures [9]. On the other hand traditional dressings e.g. bandages and gauzes are made of cotton wool have some disadvantages e.g. they are adhesive to tissue and cell and be more adhesive to the wound after the exudates fluid solidifies as a result patients feel pain and lost some new generating tissue during removal. To minimize such risks and disadvantages our research objective is to develop hydrogels containing honey together with plant derived glucosylceramide for the resuscitation of burns. Hydrogels are biomaterials with three dimensional hydrophilic polymeric network capable to absorb/ swollen water andexudates from atmosphere [10]. Theycontrol moist environment helps to wound healing [11], create cushioning and cooling effect to wound area [12], capable to stop wound dryness. Hydrogels are also easily removable; spread more easily, biodegradable, non- toxic, elastic, biocompatible, cost effective, non staining water soluble and compatible with several excipients [13]. Epidermal growth factor (EGF), silver sulfadiazene (SS), Amniotic membrane, skin grafting, boiled potato peel, honey, banana leaf, soframycin creamare some example whichare being used as a dressing materials for dressing the burn wounds among them honey is the cheap, easily available and reasonably good dressing material in developing countries. In burn treatment honey help to accelerate healing with reduce scarring of wounds. [14] Both topically and systemically dressings with honey increase wound healing, $[15,16]$ when compared to silver sulfadiazene (SS) honey help to do wound sterile in short time, and have better effect in periods of incidence of post burn contractures and hypertrophic scars [17]. From ancient time honey has been used to wound treatment [17-19]. Honey naturally supernaturated sugar solution containing glucose, maltose, fructose, sucrose with carbohydrate and $17 \%$ water $[20,21]$. So it can helps to creating a moist environment for treating burns. Honey has anti-parasitic [22], anti-inflammatory [23], anticancer [24, 25] and antibacterial properties [26]. The antibacterial activity of honey may help to accelerates wound healing process $[25,27]$ and using honey in burn healing there have not found any adverse effect [28]. On the other hand, recent studies suggest that in burns or in people having dry skin supplementing of intercellular sphingolipids of the stratum corneumstimulate the activity of the skin [29]. The anima Iglycosphingolipid is similar to the glycosphingolipid extract from rice bran; in which ceramide is the backbone of the glycosphingolipid including fatty acid in an amide linkage along sphingoid bases, and the hydroxyl group is substituted by glucose. As a result of different fatty acid components and chemical structure of sphingoid bases there are many types of glycosphingolipids present in nature. Till now, over twenty molecular sphingolipids species have been identified in rice bran. The representative structure of glucosylceramides in rice bran was set up by experiment of several chromatograph and NMRspectra, as demostrated in Fig. 1 [30].

Ceramide is the essential element of stratum corneum (50\%) of the epidermis layer of human skin [3135]. It play a crucial role in skin care by making a barrier which protect from bacterial infection, environmental stress and dehydration (keep skin moisture and smoothness). [36]

Because of its role in water holding properties and maintaining the skin barrier function of the epidermis $[37,38]$ ceramide has high profitable potential in pharmaceutical industries for uses in skin care products. Many products containing ceramide have already been investigated and found effective for skin care. Hydrophilic ointment containing $0.1 \%$ ceramide was found to have good healing effects on patients of 
atopic dermatitis [39]. Hydrocolloid dressing containing $0.3 \%$ ceramide accelerated skin erosion [40]. Ceramides also effective in recovering the water content of dry skin and in alleviating atopic eczema [41]. These studies indicate that ceramide can be used as an active component in dermatological therapy. Ceramides may be incorporated in the honey to form emulsions by constructing hydrogels. Like body tissues hydrogels are capable of holding high amounts of water. It has hydrophilic 3D polymer networks. High water holding capacity allows hydrogels to protect them from rapid degradation and encapsulate therapeutic molecules. Large water content, rubbery consistency, low interfacial tension and softness have make them useful materials for application on wound caused by burns [42]. Every these outcomes support the favorable effects of skin lipid supplementation conferred their similarity to the stratum corneum lipids both in composition and in the structuring of the dressing materials using ceramide containing hydrogels [43]. Therefore, the combination of the essential compound ceramides and the natural honey in the form of hydrogels for treatment of burn skin and use like emulsion will make them very useful, cost effective and available dressing materials for burn patients.

Gelatin is almost tasteless, odorless natural protein, obtained from animal skin or bone by partial degradation of collagen. It's biocompatible, hydrophilic and biodegradable substance. It can absorb more than 5 to 10 times water as its weight itself [44].Gelatin helps to prevent excess water (exudates composed of serum, wound fluids) and cell debris which come out of the wound, as a result, accelerate of wound healing [45-47]. PVA is one the important polymer used to prepare hydrogel biomaterial due to their excellent properties.It used to prepare in wound dressing material due to their properties like solubility in water, biodegradable, non-toxic, water retention properties $[48,49]$, biocompatibility, swelling properties, curative dermal benefits [50, 51], non- carcinogenic and excellent film forming ability [52]. The Crosslinking agent glutaraldehyde has been used for crosslink to PVA with Gelatin for hydrogel membrane preparation [53]. Glycerine was used as plasticizers to the raise strength and flexibility of biomedical hydrogel membrane. It help to increase chain flexibility, resistance to fracture and decline density, viscosity of polymer [54].

\section{Experimental Methods}

\section{Materials}

Ceramide was purchased from Oryza Fat oil and chemical company Itd, Japan. Glycerin, Poly vinyl alcohol (PVA) and glutaraldehyde (GA) were purchased from Sigma Aldrich, Germany. Honey (AussieBee, Australia) was purchased from local market Bangladesh. Gelatin was collected from Global Capsules Ltd., Bangladesh and Gelita Ltd., Germany. Mice (Swiss Albino) werecollected from Pharmacology Lab, Jahangirnagar University of Bangladesh. Microorganism (Eshchericia coli, Staphalycoccas aureus \&Candida albicans) was collected from cell and tissue engineering lab of MIST. Distilled water and molecular biology grade water was used throughout the experiments.

\section{Preparation Method Hydrogel Dressings Membrane}


The hydrogel dressing's membrane was prepared by following solution casting method. Briefly, first prepare ceramide solution by adding ceramide powder in water. Prepare gelatin solution by adding gelatin, glycerin\& water as ratio of 2.26:1:2 with continuous heat \& stirring. Then prepare 10\% PVA solution by adding PVA powder in water with continuous heat $\&$ stirring. Now ceramide solution added in PVA solution to form PVA-Ceramide solution. Add gelatin solution into PVA-Ceramide solution to form PVA-Ceramide- Gelatin solution. Add $3 \mathrm{ml}$ Honey and finally add crosslinking agent $(0.5 \mathrm{ml} \mathrm{GA}+0.05 \mathrm{ml}$ $\mathrm{HCL}+10 \mathrm{ml}$ water). Heat and stirring was continued for whole process. Temperature kept between $50^{\circ} \mathrm{C}$ to $70^{\circ} \mathrm{C}$ for total process. Now the final solution was poured into petri dish and left for $48 \mathrm{hrs}$ to form hydrogel biomaterials.

\section{Water Vapor Transmission Rate (WVTR).}

For WVT measurements, test tube was taken with $1.95 \mathrm{~cm}$ mouth diameter and $10 \mathrm{ml}$ of molecular biology grade water into it. The open test tube was enveloped with hydrogel dressing's membrane and staunched by applying Teflon tape. The test tube was weighed and at $40^{\circ} \mathrm{C}$ temperature placed in an oven for one day (24 hours). After $24 \mathrm{~h}$ taken out of the test tube was from oven and took weight again. By using formula the water vapor transmission rate (WVTR) was measured [55]:

\section{WVT $=\left(W_{i}-W_{f}\right) /(A \times 24) \times 10^{6}\left(\mathrm{gm} / \mathrm{m}^{2} \mathrm{~h}\right)$}

$A=$ area of the round mouth of test tube;

$\mathbf{W}_{\mathbf{i}}$ and $\mathbf{W}_{\mathbf{f}}$ were the initial and final weight of test tube, respectively.

\section{Moisture Retention ability.}

For moisture retention ability measurement, the hydrogel dressing's membranes were cut into same pieces and depth and weighed then placed in an oven for $5 \mathrm{~h}$ at $45^{\circ} \mathrm{C}$. By using following formula the moisture retention capability was measured [56]:

\section{Moisture retention capability $(\%)=\left(W_{f} / W_{i}\right) \times 100$}

$\mathrm{W}_{\mathrm{f}}=$ weight before placing in an oven and

$\mathrm{W}_{\mathrm{t}}=$ weight after $5 \mathrm{~h}$

\section{Gel Fraction}

Prepared hydrogel dressing's membranes were cut into same pieces then placed in a vacuum oven and waited for gained the constant weight. Then hydrogel membranes were weighed. Then for 4 days the hydrogels membranes were immersed in distilled water. These hydrogel dressing's membranes were 
taken out of water after 4 days and placed again in vacuum oven to gain a constant weight. By using following formula the gel fraction was measured [57]:

Gel fraction $(\%)=\left(W_{f} / W_{i}\right) \times 100$

$\mathbf{W}_{\mathrm{i}}=$ weight after placing in vacuum oven, and

$\mathbf{W}_{\mathbf{f}}=$ weight when the wet samples were dried in vacuum oven.

\section{Porosity Evaluation}

Porosity $(P)$ of the hydrogel was determined by the liquid displacement method by following the equations as described below [58].

\section{$P=\left(S_{1}-S_{3}\right) /\left(S_{2}-S_{3}\right) \times 100$}

Here, $\mathbf{S}_{\mathbf{1}}=$ solvent volume (initial), $\mathbf{S}_{\mathbf{2}}=$ solvent volume after the sample immersion, $\mathbf{S}_{\mathbf{3}}=$ solvent volume after withdrawal of sample.

\section{Measurement of Swelling Behavior of Hydrogel Dressing's Membrane}

The swelling behavior of hydrogel dressing's membrane was measured by dissolving the hydrogel different physiological solution (e.g. blood, water, $0.9 \% \mathrm{NaCl}, \mathrm{PBS}, 0.9 \% \mathrm{MgCl}_{2}, 5 \%$ Dextrose. The hydrogel dressing's membranes were cut and weighed to measure the swelling behavior. Then the hydrogel membranes were immersed in these physiological solutions for $1.5 \mathrm{hr} \& 3 \mathrm{hr}$. After time interval, hydrogel membranes were withdrawal from the solution and surface of the hydrogel was dried with filter paper to dry and erase any droplets and took weight again. By using following formula swelling behavior was calculated [59]:

\section{Swelling ration $(\%)=\left(W_{s}-W_{d}\right) / W_{d} \times 100$}

$\mathrm{W}_{\mathrm{s}}=$ weight of swelled membrane and

$W_{d}=$ weight of dry membrane.

\section{Evaluation of Antimicrobial Activity.}

Antimicrobial activity of hydrogels was determined by using diffusion method [60] against E. coli (ATCC 8739) and Staphylococcus aureus (ATCC 9749) as model gram (-) ve and gram (+) ve bacteria respectively and Candida albicans (ATCC 10231) as fungi. PVA- Gelatin hydrogels were used as control. The test specimens were $\mathrm{C} 1$ hydrogel, $\mathrm{C} 2$ hydrogel, $\mathrm{CH}$ hydrogel\& $\mathrm{H}$ Hydrogel. Test specimens were placed in MHA medium inoculated with S. aureus. At $37^{\circ} \mathrm{Ctemperature} \mathrm{incubated} \mathrm{for} 24 \mathrm{~h}$ after which measured the 'Zone of Inhibition'. After the incubation the antibacterial and antifungal activity was evaluated on the basis of zone of inhibition formed. 


\section{Scanning Electron Microscope (SEM)}

The hydrogel was freeze dried before investigated by SEM. The structure of the surface of hydrogel membranes was experimented by using FESEM (field emission scanning electron microscope) (Model: JOEL JSM-7600F). The sample was covered by a thin gold conductive layer before analysis. To create the layer a sputter coater was used. Using accelerating voltage of $5 \mathrm{kV}$, with a secondary electron detector was used for observing hydrogel surface.

The structure of surface of hydrogel dressing's membrane was investigated by SEM as shown in Fig.

\section{UV-Spectroscopy.}

The hydrogel membranes solution prepared was characterized using ultra-violet-visible spectroscopy (Specord 205, Germany). For UV analysis spectra range was 200-600 nm, CH hydrogel were immerged in deionized water then ceramide particles and honey were eliminated into the deionized water samplefrom the swollen hydrogel samples and for background correction deionized water were used for UV spectra recording. Then from this medium sample was taken to measure the absorption spectra.

\section{Fourier Transform Infrared Spectroscopy (FTIR) Analysis:}

FTIR (Shimadzu, IR Prestige 21 PC) was performed to evaluate the major functional group, chemical structure, contents and structural changes happened in hydrogel. The FTIR range was $4000 \mathrm{~cm}^{-}$

${ }^{1}$ to $400 \mathrm{~cm}^{-1}$ for the hydrogel membranes. In case of hydrogel membranes (Control and $\mathrm{CH}$ Hydrogel) the samples were dried properly to make powder form. Then pellets were prepared including the $\mathrm{KBr}$ (infrared grade) by pressing and then took the pellet in the FTIR-machine for experiment. At room temperature all analysis was accomplished.

\section{$\underline{\text { In-Vitro Burn Healing Procedure }}$}

Animal: Nine albino mice age 8 weeks old and weight 30-35 g were collected for the experiment. All mice's were separately kept in polyethylene cages under room temperature $23 \pm 2{ }^{\circ} \mathrm{C}$. Throughout the study all tested animals were fed on commercial pellet and supplied water ad libitum. The Animal Care, Handling and Use Committee of The Jahangirnagar University in Bangladesh was approved the experimental protocol and the study was done following animal welfare guidelines and regulations.

Experimental Design: All mice were divided into 3 groups:

- Group- I: Control group (Negative). No treatment was applied.

- Group- Il: Animal treated with $\mathrm{CH}$ - Hydrogel dressing.

- Group- III: Animal treated with C2- Hydrogel dressing.

Applied anaesthetic ether for anaesthetized tested animal and used electric clipper with shaving cream for removing hair on the back of the mice. By using 70\% iso propyl alcohol (IPA) disinfected the shaved 
area. The burn wounds were created as reported in literature [61]. Briefly, $10 \mathrm{~mm}$ diameters a cylindrical metal rod was heated over an open flame for 60 seconds then hold and pressed to the shaved and disinfected dorsal mouse skin surface for 30 seconds under light ether anesthesia.

\section{Measurement of wound area:}

By digital slide caliper on $0,3,7,10,15$ day before treatments application the reduction in burn edge diameter was measured $(\mathrm{mm})$. The reduction of the initial burn diameter was represented burn edge contraction. All data were recorded for further analysis.

\section{Determination of the burn wound healing rate:}

By using the following formula the burn area reduction rate was calculated:

Burn wound reduction rate $=\left(A_{2} / A_{1}\right) \times 100$

Where $\mathbf{A}_{1}=$ the initial areaand

$\mathrm{A}_{2}=$ the wound area at time $\mathrm{t}$,

\section{Histological Analysis}

Histological analysis was performed by using light microscope. Tissue samples were collected from skin of mice and fixed with $10 \%$ formalin. After fixation samples were stained with H\&E (hematoxylin- eosin), all images were recorded by light microscope.

\section{Result And Discussion}

\section{Water vapor transmission rate (WVTR)}

Too high value of WVTR may lead to rapidly dry the wound, resulting a scar formation, on the other hand too lower value of WVTR may lead to accumulation of exudates, resulting risk of bacterial infection and delayed healing process [62]. So an ideal hydrogel dressings WVTR value should not have either too much or too less and should control evaporation of water from a wound at an optimal rate. An ideal dressing should also have less WVTR value than WVTR compare with 2nd and 3rd degree burn in skin , respectively which is $178.55 \pm 4.5 \mathrm{gm}^{-2} \mathrm{~h}^{-1}$ and $143.2 \pm 4.5 \mathrm{gm}^{-2} \mathrm{~h}^{-1}$ [63].

In this study, the WVTR of four samples C1, C2, CH and H were $97.23,45.56,49.97$ and $23.58 \mathrm{~g} / \mathrm{m} 2 \mathrm{~h}$ respectively (Shown in Figure 2). The WVTR value of $\mathrm{C} 2$ and $\mathrm{CH}$ is comparable to Duoderm (UK) hydrocolloid dressings which have been reported to have $37.04 \pm 2 \mathrm{~g} / \mathrm{m} 2 \mathrm{~h}$ WVTR value [64]. Both results also comparable with WVTR value of PVA-Clay nanocomposite hydrogel for wound dressings are 35$56 \mathrm{~g} / \mathrm{m} 2 \mathrm{~h}$ [65]. So we can say that these two dressings could not only prevent dehydration, but also protect wound from excess hydration. 


\section{Moisture Retention Capability}

Too much moisture loss from the wound may lead to a body temperature fall that may high metabolic rate. [66]. On the other hand too much accumulation of moisture may build up risk of bacterial infection and bad odor. So ideal dressing should need to maintain optimal moisture content at the wound surface and it's very crucial in burn injury. In this study we found too less moisture retention capability for control (only PVA and Gelatin hydrogel) which was only $28 \%$. After addition of ceramide the moisture retention capability increase to $32.69 \%$ and $33.88 \%$ for $\mathrm{C} 1$ and $\mathrm{C} 2$ hydrogel dressing respectively (Shown in Figure $3)$. Again addition of honey the moisture retention of $\mathrm{H}$ hydrogel dressing was almost $50 \%(47.33 \%)$. But addition of both ceramide and honey together we have found an optimum moisture retention capability for $\mathrm{CH}$ hydrogel dressing which was $43.66 \%$. The moisture retention capability of $\mathrm{CH}$ hydrogel dressing ( $43.66 \%$ at $40^{\circ} \mathrm{C}$ in $5 \mathrm{~h}$ ) was comparable with the moisture retention capability of PVA/PEG/agar based wound dressings was about $40 \%$ at $37^{\circ} \mathrm{C}$ in $5 \mathrm{~h}$. [67] So $\mathrm{CH}$ hydrogel dressing was recommended for burn injury which moderately losing moisture from wound.

\section{Gel Fraction}

It shows the crosslinking behavior of the hydrogel. The observed result of gel fraction in these studies for investigated all hydrogel dressing showed proper Crosslinking. As per reported on Kim et al 2008 \&Ajji et al 2005, as the gel fraction decreased, the flexibility of hydrogel was increased $[68,69]$ According the report, in this studies we have found $\mathrm{CH}$ and $\mathrm{H}$ was more flexible hydrogel dressing with moderate strength (Shown in Figure 5). We have also observed the hydrogel with honey gave lower gel fraction than did the hydrogel without honey. Honey reduced the Crosslinking interaction between PVA and Gelatin. On the other hand hydrogel with higher ceramide gave lower gel fraction and lower gave higher gel fraction.

\section{Porosity}

Porosity of control was $70 \%$, after incorporation of $5 \% \& 2.5 \%$ ceramide and honey it was reduced to $50 \%$, $55.56 \%$ and $58 \%$ for $\mathrm{C} 1, \mathrm{C} 2$ and $\mathrm{H}$ hydrogel respectively (Shown in Figure 6 ). The reduction of porosity for $\mathrm{C} 1, \mathrm{C} 2$ and $\mathrm{H}$ - hydrogel due to incorporation ceramide into PVA \& Gelatin and high density of honey range between 1.38 to $1.45 \mathrm{~kg} / \mathrm{l}$ at $20^{\circ} \mathrm{C}$ [70]. On the other hand, after addition of ceramide the porosity reduced to $50 \%$ and $55.56 \%$, it's due to incorporation and interaction of ceramide with PVA and Gelatin. Higher the ceramide concentrations lower the porosity. The lowest porosity was found for $\mathrm{CH} 32.26 \%$ its due to both dense honey and ceramide incorporation into the hydrogel dressings. For an ideal dressing porosity is an important factor for cell migration, proliferation and nutrition supply. On the other hand dense surface also important for dressing material because it does not allow bacteria to penetrate, that can responsible for microbial infection to burn wound. So from these studies we found $\mathrm{CH}$ hydrogel with $32.26 \%$ porosity, which was not too much porous or too much dense dressing's material. It was better for cell migration, proliferation, nutrition supply as well a good barrier against bacteria and help to absorb excess moist \& exudates.

\section{Swelling Behavior}


Among all prepared hydrogel $\mathrm{CH}$ hydrogel was showed best swelling result in $5 \% \mathrm{DA}, 0.9 \% \mathrm{MgCl}_{2}, \mathrm{PBS}$ and Blood solution. Compare with control all other hydrogels also showed good result for swelling (Figure $7(a-f))$.

\section{Evaluation of Antimicrobial Activity}

Antimicrobial activity of $\mathrm{C2}, \mathrm{CH}$ and $\mathrm{H}$ hydrogel was investigated against Staphylococcus aureus (gram $+\mathrm{ve}$ ) and Escherichia coli (gram -ve) bacteria and Candida albicans fungi (Figure 8). The zone of inhibition only found against $\mathrm{S}$. aureus by $\mathrm{CH}$ and $\mathrm{H}$ hydrogel, its may be due to presence of honey in the hydogel. Honey has a strong antibacterial activity against bacterias $[25,27]$. On the other hand no zone of inhibition were found for these hydrogel against E. coli and Candida albicans its may be due to less volume of honey in the hydrogel.

\section{SEM}

The surface morphology of control (only PVA \& Gelatin) and CH Hydrogel were experimented by SEM as shown in Figure 9. It was noticed that $\mathrm{CH}$ hydrogel surface was both dense and porous. At very large magnification in $\mathrm{CH}$ hydrogel there have well marked presence of dense surface and porous surface. Both dense and porous surface will beneficial for hydrogel dressing finally for wound healing. Dense surface did not permit the entrance of bacteria in wound area. On the other hand porous surface did allow the cell migration, nutrition supply, proliferation and help to absorb excess moist and serum exudates from wound area. Due to presence of porous structure it also helps to influences in degree of swelling.

\section{UV Vis Spectroscopy}

The prepared $\mathrm{CH}$ Hydrogel were characterized by UV visible spectroscopy. Figure 10 depicts the UV spectrum of $\mathrm{CH}$ hydrogel showed a characteristics absorption band in $260 \mathrm{~nm}$ and $295 \mathrm{~nm}$. The absorption band $260 \mathrm{~nm}$ indicates the presence of ceramide in the solution $[\mathbf{7 1}, \mathbf{7 2}]$ and the absorption band $295 \mathrm{~nm}$ indicates the presence of honey in the solution [73]. Both absorption band slightly different from previous studies, it might be due to the source variations.

\section{Fourier Transform Infrared Spectroscopy (FTIR) Analysis}

In our current research we have investigated FTIR studies to confirm the hydroxyl group present in hydrogel dressings, because which are reason for the water restoring capability of the hydrogel.

Our prepared hydrogel membrane showed the free hydroxyl groups present in the membrane. In the case of $\mathrm{C}_{2}$ hydrogel dressing, Figure 11a \& Table 2, peak at $3394.72 \mathrm{~cm}-1$ indicated the presence of free hydroxyl groups and peak at $2927.94 \mathrm{~cm}-1$ showed the $\mathrm{C}-\mathrm{H}$ stretching. The spectra of the dressing membrane also showed peak at $1649.14 \mathrm{~cm}-1,1541.12 \mathrm{~cm}-1$ and $1454.33 \mathrm{~cm}-1$ implying the presence of amide bond of ceramide between sphingosine and fatty acid. The membrane also showed peak at $1039.63 \mathrm{~cm}^{-1}$ refers to $\mathrm{CO}$ stretching vibrations of aldehyde group of glutaraldehyde and peak at 852.54 $\mathrm{cm}^{-1}$ refers to $\mathrm{CH}_{2}$ stretching. 
In case of $\mathrm{CH}$ hydrogel dressing, Figure $11 \mathrm{~b}$ \& Table 3, peak at $3380.66 \mathrm{~cm}-1$ conveyed the presence of free hydroxyl groups and peak at $2933.77 \mathrm{~cm}-1$ represented the $\mathrm{C}-\mathrm{H}$ stretching. The hydrogel showed peak at $1649.14 \mathrm{~cm}^{-1}, 1544.98 \mathrm{~cm}^{-1} \& 1411.88 \mathrm{~cm}^{-1}$ implying the presence of amide bond of ceramide between sphingosine and fatty acid. It also showed peak of fructose and glucose at $1242.16 \mathrm{~cm}^{-1}$ and $1336.67 \mathrm{~cm}^{-1}$ that represents to the $\mathrm{CO}$ stretching in $-\mathrm{COH}$ group and $\mathrm{C}-\mathrm{C}$ stretching in carbohydrates.

\section{In- Vivo Burn Healing Procedure}

The treatment was applied for 15 days. The essential process for burn healing is burn edge contraction that leads to wound closure. The bun wound edge contraction was expressed as increase of healing rate. So determination of burn wound area was main criteria for observing wound healing progression. Both $\mathrm{C} 2$ and $\mathrm{CH}$ hydrogel showed regular burn wound edge contraction during the application of treatment (Figure 12). The maximum burn diameter contraction was recorded for $\mathrm{CH}$ hydrogel. This may be due to the presence of both honey and ceramide into the hydrogel. Previous studies in mice model showed honey hydrogel quickened wound repairing process by increasing re-epithelialization and lowering the inflammatory response [74]. The result of $\mathrm{C} 2$ hydrogel was also significant. Presence of ceramide may play a vital role wound healing. Ceramide loaded in hydrophilic ointment [75] and hydrocolloid dressing [76] showed rapid wound healing in mice model. Both $\mathrm{C} 2$ and $\mathrm{CH}$ hydrogel showed optimum result for wound healing when moisture retention capacity water vapor transmission rates (WVTR) were investigated. As we an ideal dressing should have good moisture retention capability and WVTR for wound healing.

\section{Histological analysis}

This may be due to the release of ceramide and into the media, (Figure 11), which may regulate and influence the cell proliferation, differentiations and apoptosis of epidermal cells to the wounded area [77]. It is known that the ceramides selectively disallow the prolapse of the protein kinase $\mathrm{C}$ isoform $\mathrm{PKCa}$ thus affecting cell growth [78]. On the other hand honey increases the healing rate $[\mathbf{7 9}, \mathbf{8 0}]$ by stimulating leukocytes to cytokines and growth factors release that activate tissue repair [81] and by stimulating the keratinocytes transcription of genes for TNF-a, IL-1ß and TGF-ß. [82]

\section{Conclusion}

This is the first study that uses ceramide in combination with honey to produce biomedical hydrogels for burn wound treatment. Our results clearly indicate the based on the results obtained in the present study, the use of $\mathrm{CH} \& \mathrm{C}_{2}$ hydrogel is effective for promoting and accelerating burn wound healing. As a future plan, addition of other antibiotic like Mupriocin with ceramide and honey to boost up the antimicrobial properties.

\section{Declarations}




\section{Acknowledgments}

Author is like to thanks Khairul Islam who are the Scientist of Wazed Miah Science Research Center for supporting FTIR and UV analysis. Also thankful to Md. Habibur Rahman Previous student of Pharmacy Department, Gono Bishwabiddalay and current Production Pharmacist of The ACME Laboratories Ltd. for outstanding support during wound healing test on mice model, for his valuable support we could successfully conduct our animal test. Authors are also like to thanks to authority of Tissue Engineering Lab, Military Institute of Science and Technology for overall support.

\section{Conflict of interest}

The authors declare that they have no conflict of interest.

\section{References}

1. Kumar S, Ali W, Verma AK, Pandey A, Rathore S. Epidemiology and mortality of burns in the Lucknow region, India: a 5 year study. 2013;39 1599- 1605

2. Kamoun EA, Chen X, Mohy Eldin MS, Kenawy Crosslinked poly (vinyl alcohol) hydrogels for wound dressing applications: a review of remarkably blended polymers. Arab J Chem 2015; 8 1-14.

3. Peck M, Molnar J, Swart D. A global plan for burn prevention and care. Bull World Health Organ 2009; 87 802-3

4. Available at http://www.who.int/mediacentre/factsheets/fs365/en/

5. Reid Sadoway, Emergency Medicine, American Burn Association Guidelines, USA

6. Mashreky S R et al., Injury J. Care Injured 2011; 42 507-510

7. Edwards-Jones V, Greenwood J E. What's new in burn microbiology?: James Laing Memorial Prize Essay 2000. Burns 2003; 29 15-24

8. Subrahmanyam M et al., Burns 1996; 22 491-493.

9. FDA executive summary: Classification of Wound Dressings Combined with Drugs, 2016

10. Kunal P, Banthia AK, Majumdar Starch based hydrogel with potential biomedical application as artificial skin. Afr J Biomed Res 2006; 9 23-29

11. Michaels A. Proceedings of the symposium on membrane technology membranes, membrane processes, and their applications: needs, unsolved problems, and challenges of the 1990's. Desalination 1990; 77 5-34

12. Edwards J. Hydrogels and their potential uses in burn wound management. Br J Nurs 2010; 19 S12, S14-16

13. Swarbrick J \& Boylan J C Encyclopedia of Pharmaceutical Technology. Marcel Dekker, Inc. 1992

14. Subrahmanyam M. Topical application of honey treatment of burns. J. Surg. 1991; 78 497-498

15. Yusof N, Hafiza A H A, Zohdi R M, \& Bakar M Z A. Development of honeyhydrogel dressing for enhanced wound healing. Radiation Physics and Chemistry. 2007; 76 1767-1770. 
16. Suguna L, Chandrakasan G, Thomas Joseph K. Influence of honey on collagen metabolism during wound healing in rats. Clin. Biochem. Nutr. 1992; 13 7-12

17. Moghazy A M, Shams, M E, Adly O A, Abbas A H, El-Badawy, M A, Elsakka DM et al. The clinical and cost effectiveness of bee honey dressing in thetreatment of diabetic foot ulcers. Diabetes Research and Clinical Practice. $2010 ; 89$ 276-281

18. Subrahmanyam M. A prospective randomised clinical and histological studyof superficial burn wound healing with honey and silver sulfadiazine. 1998;24 157-161

19. Yusof N, Hafiza A H A, Zohdi R M, \& Bakar M Z A. Development of honeyhydrogel dressing for enhanced wound healing. Radiation Physics and Chemistry. 2007;76 1767-1770.

20. Lee $\mathrm{H}$, Churey J J, \& Worobo R W. Antimicrobial activity of bacterial isolates from different floral sources of honey. International Journal of Food Microbiology. 2008; 126 240-244

21. Tshukudu G M, Walt M, \& Wessels Q. Comparative in vitro study of honey based and silver based wound preparations on cell viability. 2010; 36 1036-1041

22. Azim M K \& Sajid M. Evaluation of nematocidal activity in natural honey J. Bot. 2009; 41 3261-3264

23. Azim M K, Perveen H, Mesaik M A \& Simjee S U. Antinociceptive activity of natural honey in thermalnociception models in mice. 2007;21 194-197

24. Tonks A J et al. A 5.8-kDa component of manuka honey stimulates immune cells via TLR4. Leukoc. Biol. 2007;82 1147-1155

25. Swellam T et al. Antineoplastic activity of honey in an experimental bladder cancer implantation model: in vivo and in vitro studies. J. Urol. 2003;10 213-219

26. Gulfraz $\mathrm{M}$ et al. Compositional analysis and antimicrobial activity of various honey types of Pakistan. J. Food Sci. Technol. 2011;46 263-267

27. Alfonso R. Gennaro Remington, The Science and Practice of Pharmacy (Lippincott Williams \& Wilkins) $2000 ; 856$

28. Temu M J, Damian F, Kinget R \& Mooter G V D Intra-vaginal gels as drug delivery systems. Women. Health. 2004;13 834-844

29. Coderch et al., Contact Dermatitis. 2002;47 139-146

30. Fujino Y et al., Agricultural and Biological Chemistry. 1985; 49 2753-2762

31. Hill JR, Wertz PW. Structures of the ceramides from porcine palatal stratum corneum. 2009;44 291295

32. Garidel P, Fölting B, Schaller I, Kerth A. The microstructure of the stratum corneum lipid barrier: midinfrared spectroscopic studies of hydrated ceramide:palmitic acid:cholesterol model systems. Biophysical Chemistry. 2010;150 144-156

33. Feingold KR. Thematic review series: skin lipids. The role of epidermal lipids in cutaneous permeability barrier homeostasis. Journal of Lipid Research. 2007;48 2531-2546

34. Novotny J, Hrabalek A, Vavrova K. Synthesis and structure-activity relationships of skin ceramides. Curr Med Chem. 2010;17 2301-24 
35. Feingold KR, Elias PM. Role of lipids in the formation and maintenance of the cutaneous permeability barrier. Biochim Biophys Acta. 2014;1841 280-94.

36. Available at: http://www.fda.gov/ohrms/dockets/dockets/95s 0316/95s-0316-rpt0275-04-udell vol211.pdf. Accessed August 25, 2014.

37. Coderch L, López O, de la Maza A, Parra, JL. Ceramides and skin function American Journal of Clinical Dermatology, 2003;4 107-129

38. Feingold KR, Elias PM. Role of lipids in the formation and maintenance of the cutaneous permeability barrier. Biochim Biophys Acta. 2014;1841 280-94.

39. Kerscher M, Korting HC, Schiffer-Korting, M. Skin ceramides: Structure and function European Journal of Dermatology. 1991;1 39-43

40. S Tsuchiya, S Ichioka, N Sekiya, S Tajima, T Iwasaki, and S Numata. The Effect of a Hydrocolloid Dressing Containing Ceramide-2 on Split-Thickness Wounds in a Laser-Induced Erosion Model Advances In Skin \& Wound Care. 2012; 26

41. Hara S, Takahashi H, Tomiya Y. Process for preparing sphingomyelin and ceramide from erythrocyte as a starting material and a curing agent or cosmetic formulated with ceramide, U.S. Patent 5912152 1999

42. Tao Wanga et al., Carbohydrate Polymers. 2012;88 75-83

43. Guoroi Jine et al., 2013;34 724- 734

44. Budavari, S. Merck Index, (12th ed.) Whitehouse Station, NJ: Merck 1996

45. Tanaka A, Nagate T, and Matsuda H. Acceleration of wound healing by gelatin film dressings with epidermal growth factor Journal of Veterinary Medical Science. 2005;67 909-913

46. Chong E J, Phan T T, Lim I J et al., Evaluation of electrospun PCL/gelatin nanofibrous scaffold for wound healing and layered dermal reconstitution Acta Biomaterialia. 2007; $3321-330$

47. Ulubayram K. EGF containing gelatin-based wound dressings 2001; $221345-1356$

48. Peppas NA, Merril EW. Development of semicrystalline poly (vinyl alcohol) hydrogels for biomedical application J Biomed Mater Res. 1977;11 423- 434

49. Garidel P, Fölting B, Schaller I, Kerth A. The microstructure of the stratum corneum lipid barrier: midinfrared spectroscopic studies of hydrated ceramide: palmitic acid:cholesterol model systems Biophysical Chemistry. 2010;150 1-3

50. Teodorescu, M.; Bercea, M. Poly(vinylpyrrolidone) - A versatile polymer for biomedical and beyond medical applications -Plast. Technol. Eng. 2015;54 923-943

51. Darlenski J W, Surber R. Glycerol and the skin: Holistic approach to its origin and functions $J$. Dermatol. 2008;159 23-34

52. Kenawy E R, Kamoun E A, Mohy Eldin M S, El-Meligy M A. Physically crosslinked poly(vinyl alcohol)-hydroxyethyl starch blend hydrogel membranes: synthesis and characteri-zation for biomedical applications Arab J Chem. 2014; 7372-380 
53. Hassan CM, Peppas Structure and applications of poly (vinyl alcohol) hydrogels produced by conventional crosslinking or by freezing/thawing methods. In: Biopoly-mers. PVA hydrogels, anionic polymerisation nanocomposites. Springer, Heidelberg 2000;37-65

54. Vieira M G A, da Silva MA, dos Santos L O, Beppu M M. Natural-based plasticizers and biopolymer films: a review. Eur Polym J. 2011;47 254-263

55. Boonkaew B, Suwanpreuksa P, Cuttle L, et al., Hydro- gels containing silver nanoparticles for burn wounds show antimicrobial activity without cytotoxicity J Appl Polym Sci. 2014; 131

56. Roy N, Saha N, Kitano T, et al., Effectiveness of polymer sheet layer to protect hydrogel dressings. In: Starov V, Procházka K (eds) Trends in colloid and interface science XXIV. Springer, Heidelberg $2011 ; 127-130$

57. Hago E E, Li X. Interpenetrating polymer network hydrogels based on gelatin and PVA by biocompatible approaches: synthesis and characterization Adv Mater Sci Eng. 2013;1-8.

58. Dhasmana A, Singh L, Roy P, Mishra N C. Honey incorporated antibacterial acellular dermal matrix for full-thickness wound healing Ann Biotechnol. 2018; 31011.

59. Pal K, Banthia A K, Majumdar D K. Preparation and char- acterization of polyvinyl alcohol-gelatin hydrogel membranes for biomedical applications AAPS Pharm Sci Tech 2007; 8 E142-E146

60. Bauer A W, Kirby W M, Sherris J C \& Turck M. Antibiotic susceptibility testing by a standardized single disk method J. Clin. Pathol. 1966; 45 493-496

61. Reham F.El-Kased, Reham I. Amer, Dalia Attia \& Elmazar M. M. Honey-based hydrogel: In vitro and comparative In vivo evaluation for burn wound healing. Scientific reports. 2017;7 1- 11

62. John A Killion, Luke M Geever, Declan M Devine, James E K CLH. Mechanical properties and thermal behaviour of PEGDMA hydrogels for potential bone regeneration application J Mech Behav Biomed Mater. 2011; 4 1219-27

63. Nilsson $\mathrm{G}$ et al., On the measurement of evaporative water loss: methods and clinical applications. Linköping Medical Univer- sity, Linköping. 1977

64. Fisher PWAC, FOO PP, Queen D and Gaylor JDS. In vitro assessment of water vapour transmission of synthetic wound dressings 1995;16 171- 175

65. M Kokabi, M Sirousazar, ZM Hassan. PVA-clay nanocomposite hydrogels for wound dressing European Polymer Journal. 2007;43 773-781

66. Hoffman AS. Hydrogels for biomedical applications Adv Drug Deliv Rev 2002; 54 3-12

67. Soler DM, Rodriguez Y, Correa H, Moreno A, Carrizales L. Pilot scale-up and shelf stability of hydrogel wound dressings obtained by gamma radiation Radiat Phys Chem 2012,81 1249-1253

68. Kim JO, Park JK, Kim JH, Jin SG, Yong CS, Li DX, Choi JY, Woo JS, Yoo BK, Lyoo WS, Kim JA, Choi HG. Development of polyvinyl alcohol-sodium alginate gel-matrix-based wound dressing system containing nitrofurazone Int J Pharm. 2008;359 79-86

69. Ajji Z, Othman I, Rosiak JM. Production of hydrogel wound dressing using gamma radiation NuCl Instrum Methods Phys Res: Sect B. 2005;229 375-80 
70. Piotr Tomasik. Chemical and functional properties of food saccharides. CRC Press. Pp. 74. ISBN 9780-203-49572-8. 2003

71. Shoyama Y, Okabe H, Kishimoto Y, Costello C. Total synthesis of stereospecific sphingosine and ceramide J Lipid Res. 1978;19 250-9.

72. Couch L H, Churchwell M I, Doerge D R, Tolleson W H, \& Howard P C. Identification of Ceramides in Human Cells Using Liquid Chromatography with detection by Atmospheric Pressure Chemical Ionization-Mass Spectrometry Rapid Communications in Mass Spectrometry. 1997;11 504-512

73. Kanimozhi S, Kathiresan G, Kathalingam A, Kim H S \& Doss M N R Organic nanocomposite Band-Aid for chronic wound healing: a novel honey-based nanofibrous scaffold Applied Nanoscience. 2020

74. Rozaini Mohd. Zohdi et al. Honey Hydrogel Dressing to Treat Burn Wound in Rats - A Preliminary Report Pertanika Trop. Agric. Sci. 2012;35 67 - 74

75. Kerscher M, Korting HC, Schiffer-Korting, M. Skin ceramides: Structure and function European Journal of Dermatology. 1991;1 39-43

76. S Tsuchiya, S Ichioka, N Sekiya, S Tajima, T Iwasaki, and S Numata. The Effect of a Hydrocolloid Dressing Containing Ceramide-2 on Split-Thickness Wounds in a Laser-Induced Erosion Model Advances In Skin \& Wound Care. 2012; 26

77. Geilen C G, Wieder T, \& Orfanos C E. Ceramide signalling: regulatory role in cell proliferation, differentiation and apoptosis in human epidermis Archives of Dermatological Research. 1997;289 $559-566$

78. Jones MJ, Murray AW. Evidence that ceramide selectively inhibits protein kinase C-a translocation and modulates bradykinin activation of phospholipase D. J Biol Chem 1995;270 5007-5013

79. Molan PC. The evidence and the rationale for the use of honey as a wound dressing Wound Practice and Research. 2011;19 204-20

80. Boekema B K H L, Pool L, Ulrich M M W. The effect of a honey based gel and silver sulphadiazine on bacterial infections of in vitro burn wounds 2012

81. Abuharfeil N, Al-Oran R, Abo-Shehada M. The effect of bee honey on the proliferative activity of human B- and T-lymphocytes and the activity of phagocytes Food Agric Immunol. 1999; 11 169-77

82. Majtan J, Kumar P, Majtan T, et al. , Effect of honey and its major royal jelly protein 1 on cytokine and MMP-9 mRNA transcripts in human keratinocytes Exp Dermatol. 2009;19 73-9

\section{Tables}

Table 1: Zone of inhibition of $\mathrm{C}, \mathrm{CH} \& \mathrm{H}$ hydrogel dressing's biomaterials against $S$. aureus, E. coli, Candida albicans.

\begin{tabular}{|c|c|c|c|}
\hline Hydrogel Formula & \multicolumn{3}{|c|}{ Measurement of Zone of Inhibition } \\
\cline { 2 - 4 } & S. aureus & E. coli & Candida albicans \\
\hline $\mathrm{C}_{\mathbf{2}}$ & $0.00 \pm 0.00 \mathrm{~mm}$ & $0.00 \pm 0.00 \mathrm{~mm}$ & $0.00 \pm 0.00 \mathrm{~mm}$ \\
\hline $\mathrm{CH}$ & $5.10 \pm 0.05 \mathrm{~mm}$ & $0.00 \pm 0.00 \mathrm{~mm}$ & $0.00 \pm 0.00 \mathrm{~mm}$ \\
\hline $\mathrm{H}$ & $6.00 \pm 0.00 \mathrm{~mm}$ & $0.00 \pm 0.00 \mathrm{~mm}$ & $0.00 \pm 0.00 \mathrm{~mm}$ \\
\hline
\end{tabular}


Table 2: FTIR range of $\mathrm{C}_{2}$ Hydrogel

\begin{tabular}{|l|l|}
\hline Frequency & Type of Vibration \\
\hline 3094.72 & $\begin{array}{l}\text { =C-H stretching mode } \\
\text { O-H stretching mode (Carboxylic acid) }\end{array}$ \\
\hline 1649.14 & $\begin{array}{l}\text { C=C stretching mode } \\
\text { C=C stretching mode (conjugation of aldehyde with two aromatic rings) } \\
\text { C=O stretching mode (Amide) }\end{array}$ \\
\hline 1541.12 & $\begin{array}{l}\text { C=C stretching (aromatic ring) } \\
\text { N-H Bending in secondary amine }\end{array}$ \\
\hline 1454.33 & N-H Bending in secondary amine \\
\hline 1039.63 & C-O stretching mode (Alcohol, ether) \\
\hline 852.54 & $=$ C-H bending mode \\
\hline
\end{tabular}

Table 3: FTIR range of $\mathrm{CH}$ Hydrogel 


\begin{tabular}{|l|l|}
\hline Frequency & Type of Vibration \\
\hline 3380.66 & $\begin{array}{l}\text { C-H: Stretching Mode } \\
\text { N-H: Stretching Mode } \\
\text { O-H: Stretching Mode (Carboxylic Acid) }\end{array}$ \\
\hline 2933.73 & O-H: Stretching Mode (Carboxylic Acid) \\
\hline 1649.14 & $\begin{array}{l}\text { C=C: Stretching Mode } \\
\text { C=O: Stretching Mode (Amide \& Aldehyde) }\end{array}$ \\
\hline 1544.98 & $\begin{array}{l}\text { C=C: Stretching Mode (Aromatic Ring) } \\
\text { N-H: Bending in Secondary Amine } \\
- \text { NO2: Asymmetric Stretching Mode (Aliphatic \& Aromatic) }\end{array}$ \\
\hline 1411.88 & C-O-H: Bending Mode \\
\hline 1336.67 & $\begin{array}{l}\text { C-O-H, } \text {-NO2: Symmetric Mode } \\
\text { C-F: Stretching Mode }\end{array}$ \\
\hline 1242.16 & $\begin{array}{l}\text { C-O-H: Bending Mode } \\
\text { C-O: Stretching (Alcohol, Ether, Carboxylic Acid) } \\
\text { C-F:Stretching Mode }\end{array}$ \\
\hline 918.12 & C-H: Out of plane bending Mode \\
\hline
\end{tabular}

Table 4: Physicochemical characteristics of $\mathrm{C} 1, \mathrm{C} 2, \mathrm{CH} \& \mathrm{H}$ Hydrogel dressing biomaterials. 


\begin{tabular}{|c|c|c|c|c|c|c|}
\hline \multicolumn{3}{|l|}{ Parameter } & $\begin{array}{l}\text { C1 } \\
\text { Hydrogel }\end{array}$ & $\begin{array}{l}\text { C2 } \\
\text { Hydrogel }\end{array}$ & $\begin{array}{l}\mathrm{CH} \\
\text { Hydrogel }\end{array}$ & $\begin{array}{l}\mathrm{H} \\
\text { Hydrogel }\end{array}$ \\
\hline \multicolumn{3}{|c|}{ WVTR $\left(\mathrm{gm}^{-2} \mathrm{~h}^{-1}\right)$} & 97.23 & 46.56 & 49.77 & 23.58 \\
\hline \multicolumn{3}{|c|}{ Moisture Retention Capability (\%) } & 33.88 & 32.69 & 43.66 & 47.30 \\
\hline \multicolumn{3}{|c|}{ Gel Fraction (\%) } & 167.19 & 141.29 & 42.17 & 39.45 \\
\hline \multicolumn{3}{|l|}{ Porosity (\%) } & 55.56 & 50 & 32.26 & 58 \\
\hline \multicolumn{3}{|c|}{ Folding Endurance (times) } & 200 & 300 & 200 & 100 \\
\hline \multicolumn{3}{|c|}{ Spreadability $(\mathrm{mm})$} & 8 & 6 & 4 & 7 \\
\hline \multirow{12}{*}{$\begin{array}{l}\text { Swelling } \\
\text { Equilibrium } \\
\text { (\%) }\end{array}$} & \multirow[t]{2}{*}{ Blood } & $\begin{array}{l}1.5 \\
\text { hrs }\end{array}$ & 9.50 & 33.64 & 55.11 & 54.85 \\
\hline & & $3 \mathrm{hrs}$ & 14.95 & 54.01 & 66.21 & 71.22 \\
\hline & \multirow[t]{2}{*}{ PBS } & $\begin{array}{l}1.5 \\
\text { hrs }\end{array}$ & 52.29 & 62.63 & 134.85 & 50.68 \\
\hline & & $3 \mathrm{hrs}$ & 70.50 & 66.84 & 150.88 & 66.98 \\
\hline & \multirow[t]{2}{*}{$5 \% \mathrm{DA}$} & $\begin{array}{l}1.5 \\
\text { hrs }\end{array}$ & 98.96 & 82.75 & 111.63 & 106.61 \\
\hline & & $3 \mathrm{hrs}$ & 102.08 & 83.91 & 133.83 & 110.13 \\
\hline & \multirow[t]{2}{*}{$0.9 \% \mathrm{NaCl}$} & $\begin{array}{l}1.5 \\
\text { hrs }\end{array}$ & 63.93 & 44.62 & 51.62 & 94.44 \\
\hline & & $3 \mathrm{hrs}$ & 68.47 & 50.85 & 78.33 & 98.26 \\
\hline & \multirow[t]{2}{*}{$\mathrm{H}_{2} \mathrm{O}$} & $\begin{array}{l}1.5 \\
\text { hrs }\end{array}$ & 162.79 & 112.60 & 103.27 & 71.08 \\
\hline & & $3 \mathrm{hrs}$ & 208.19 & 119.93 & 150.52 & 75.06 \\
\hline & \multirow[t]{2}{*}{$\begin{array}{l}0.9 \% \\
\mathrm{MgCl}_{2}\end{array}$} & $\begin{array}{l}1.5 \\
\text { hrs }\end{array}$ & 121.17 & 69.94 & 134.85 & 50.68 \\
\hline & & $3 \mathrm{hrs}$ & 105 & 71.40 & 150.88 & 66.98 \\
\hline
\end{tabular}

\section{Figures}

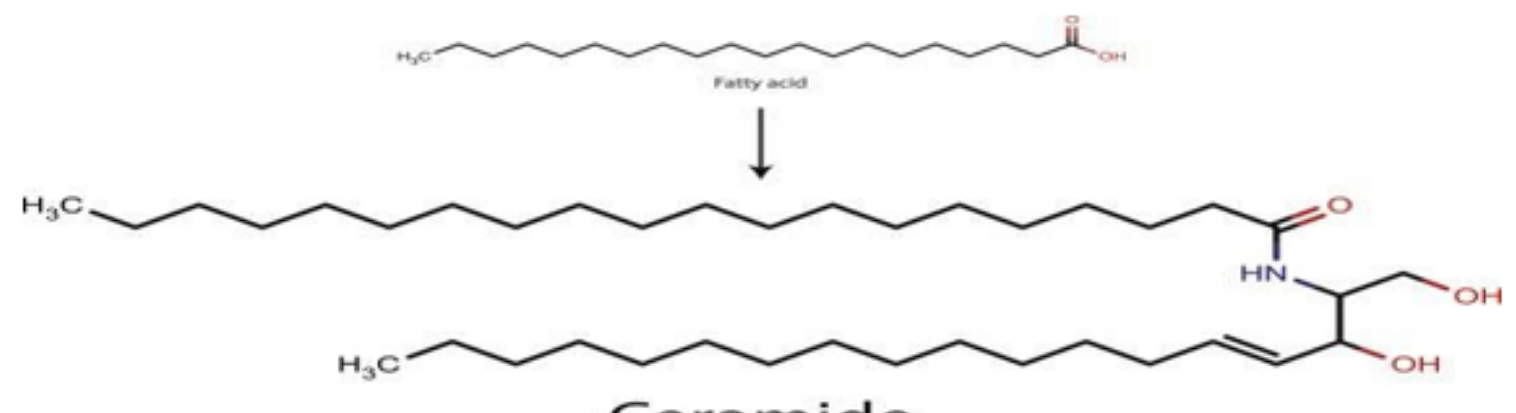

Ceramide

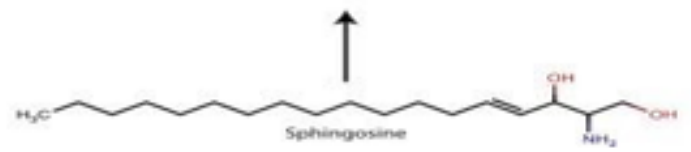


Figure 1

Structure of glucosylceramide

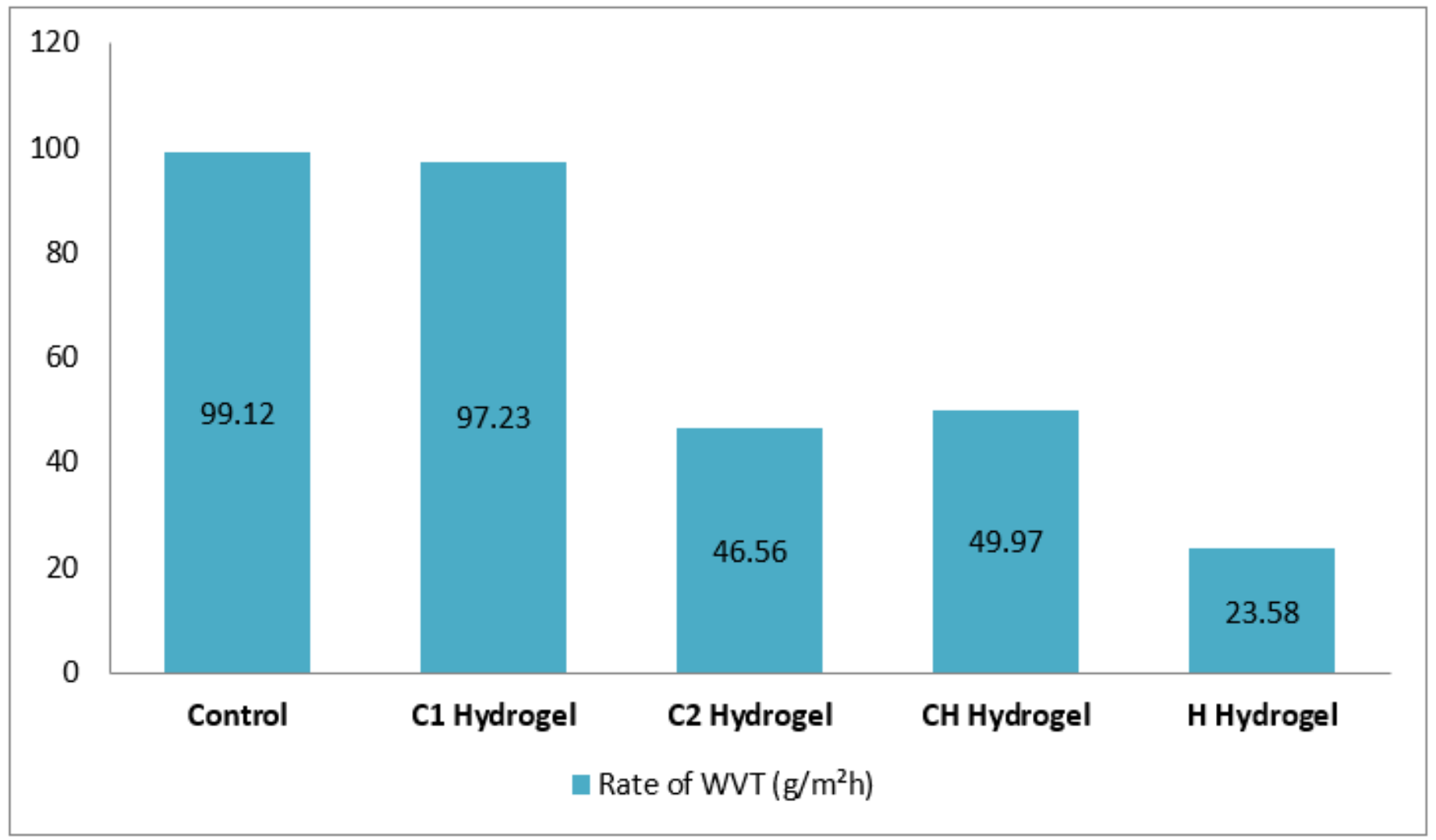

Figure 2

WVTR of Prepared Hydrogel 


\section{Moisture Retention Rate}

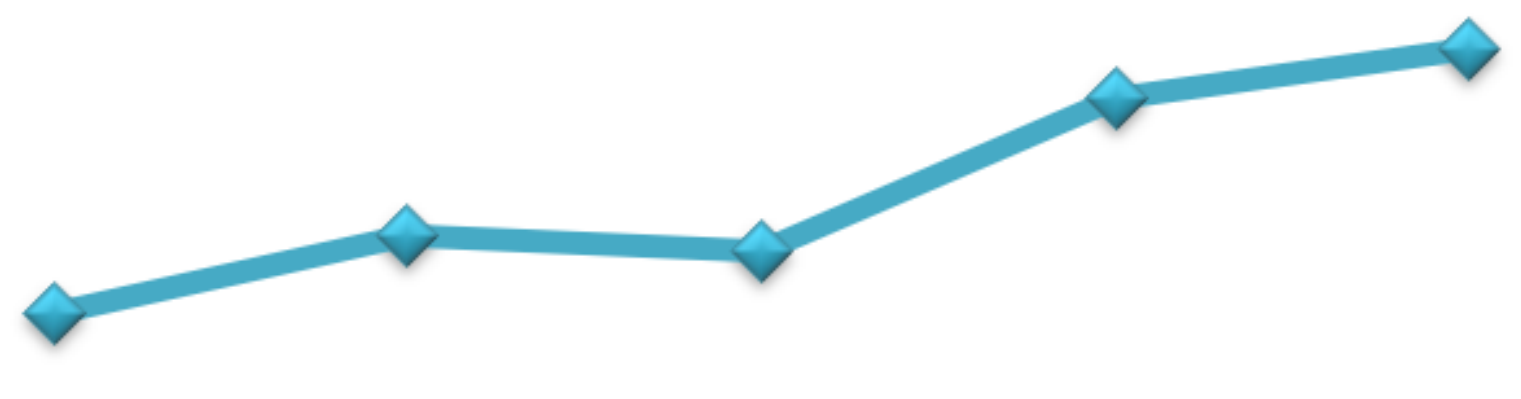

$28.36 \%$

$33.88 \%$

$32.69 \%$

$43.66 \%$

$47.30 \%$

Control

C1 Hydrogel

C2 Hydrogel

CH Hydrogel

H Hydrogel

$\Leftrightarrow$ Moisture Retention Rate

Figure 3

Moisture retention capability of Prepared Hydrogel 

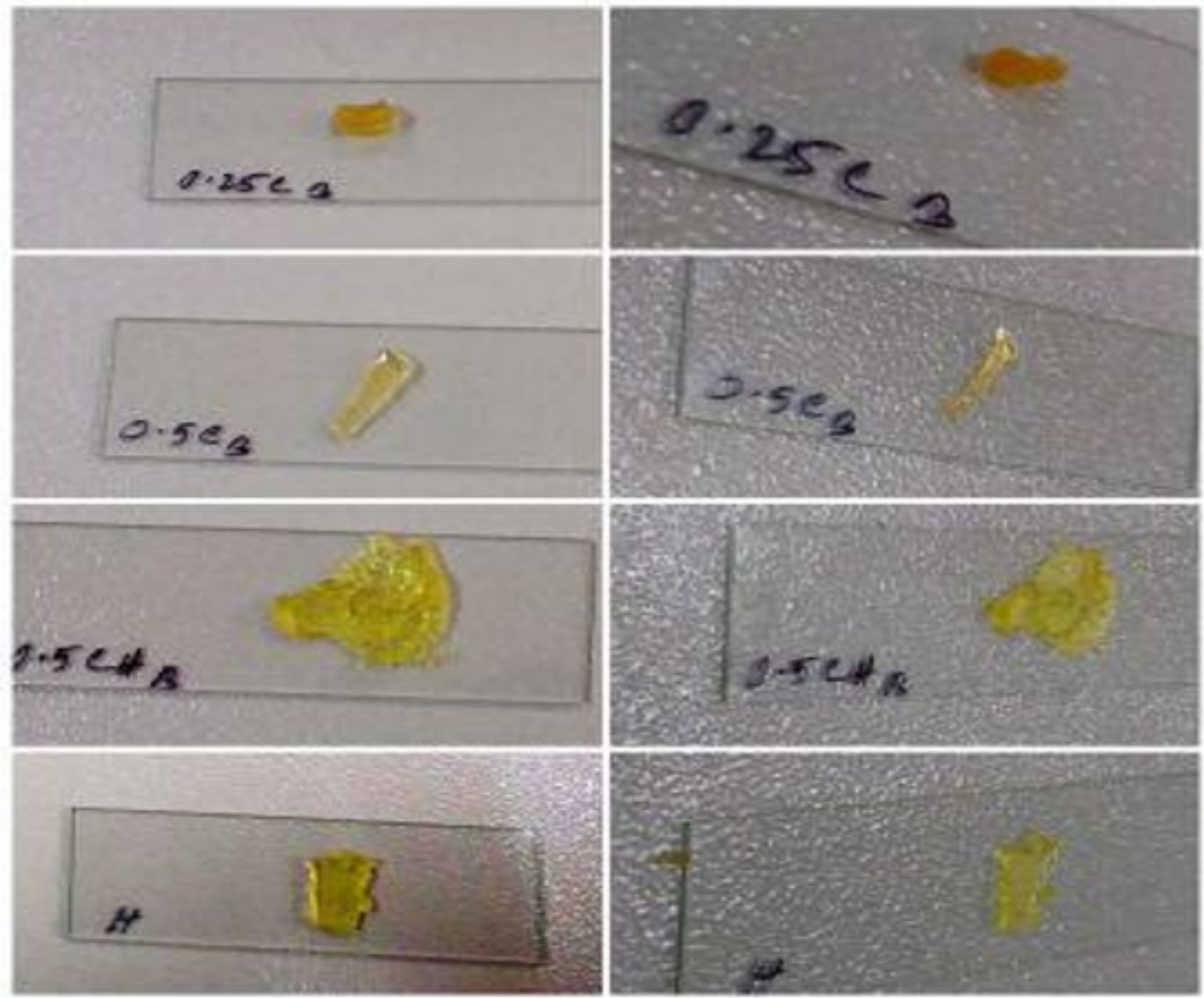

\section{Figure 4}

Moisture retention capability of hydrogel (left: before dry, right: after dry) 


\section{Gel Fraction}

$\square$ Gel Fraction

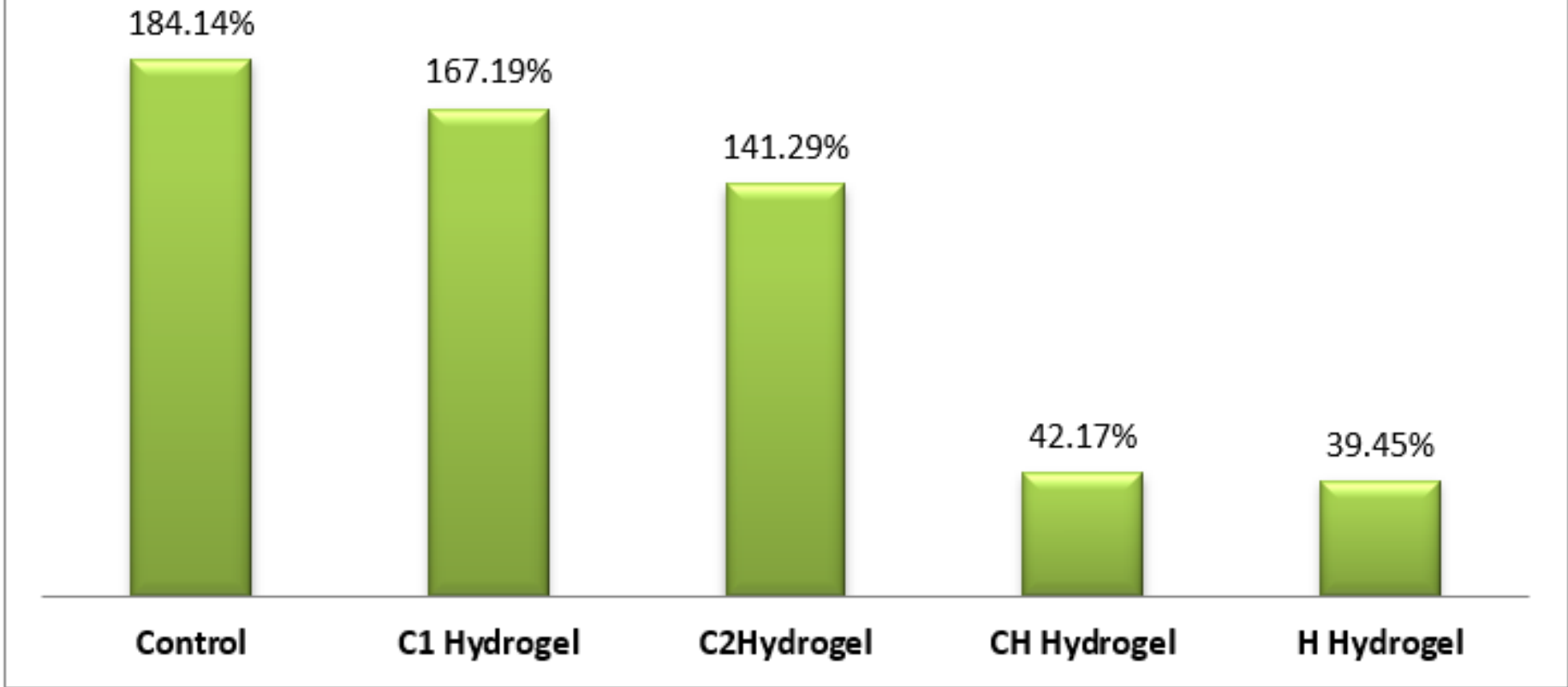

Figure 5

Gel Fraction of Hydrogels 


\section{Porosity}

$\leadsto$ Porosity
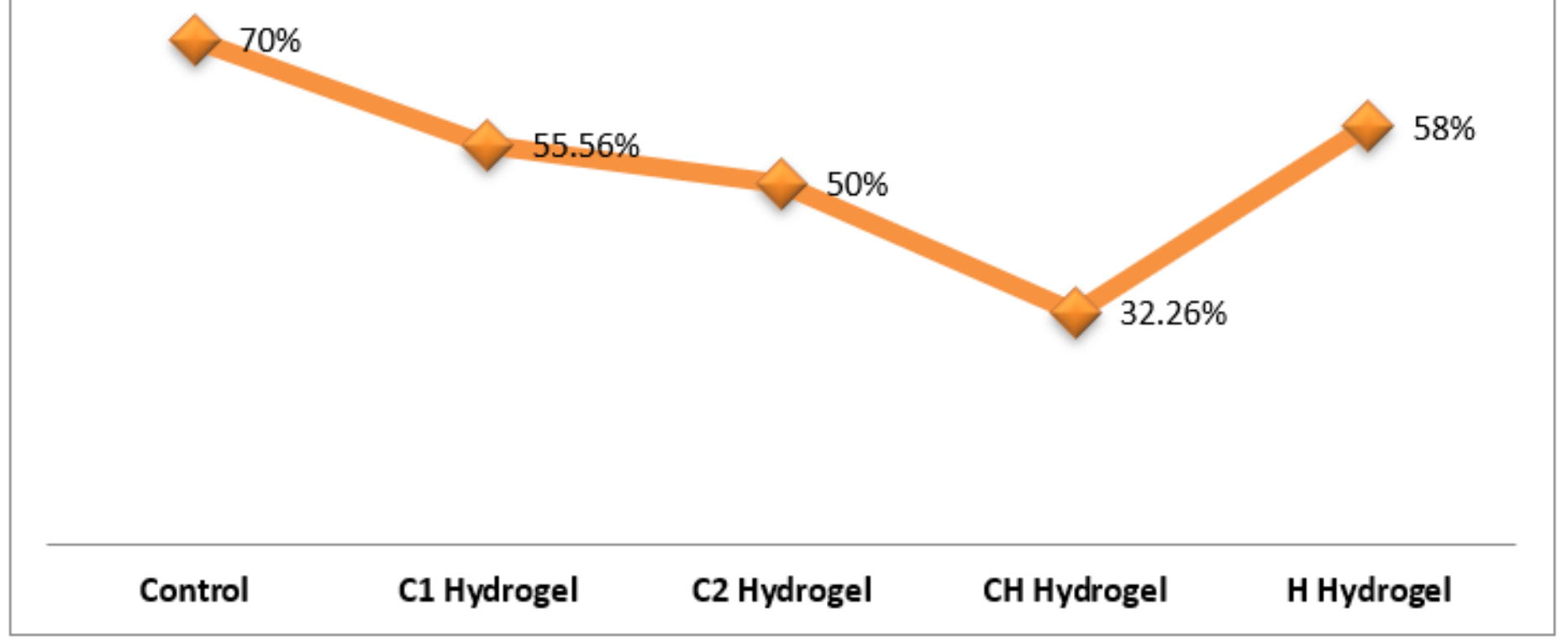

Figure 6

Porosity of Hydrogels 


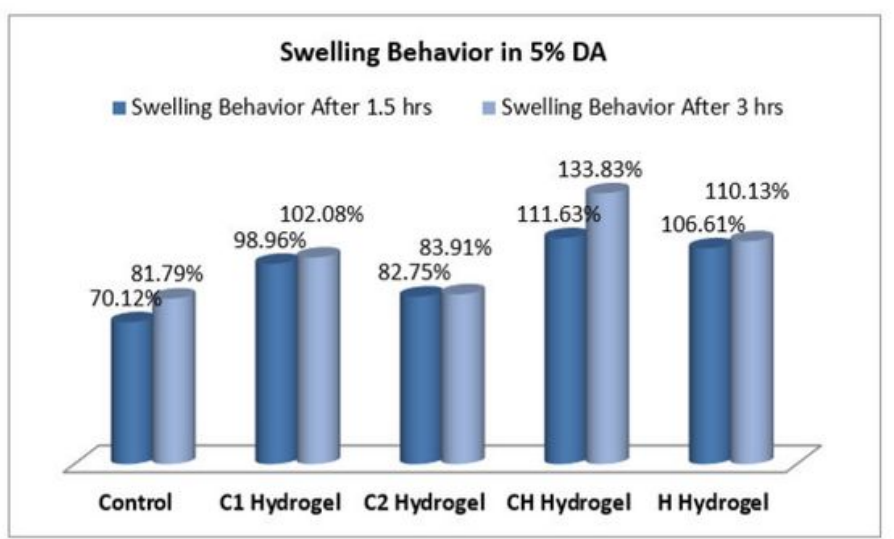

Figure 7- a: Swelling Behavior of hydrogel in 5\% DA

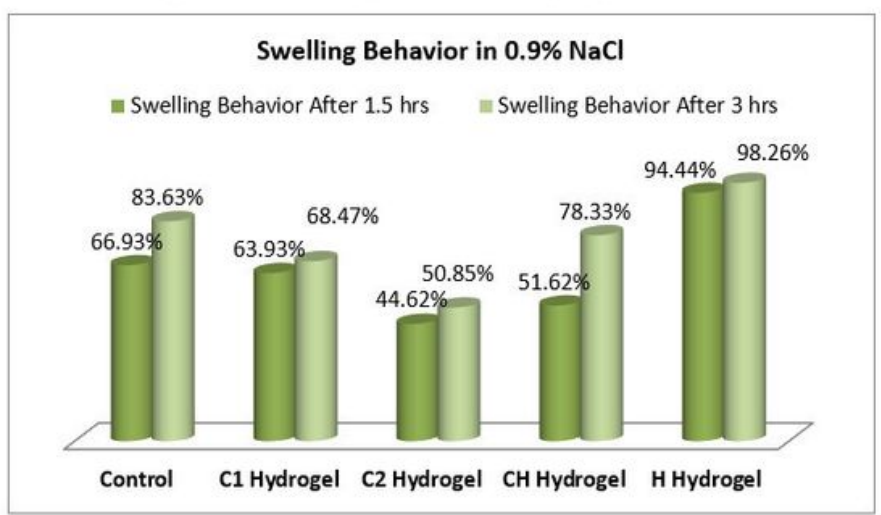

Figure 7- b: Swelling Behavior of hydrogel in $0.9 \% \mathrm{NaCl}$

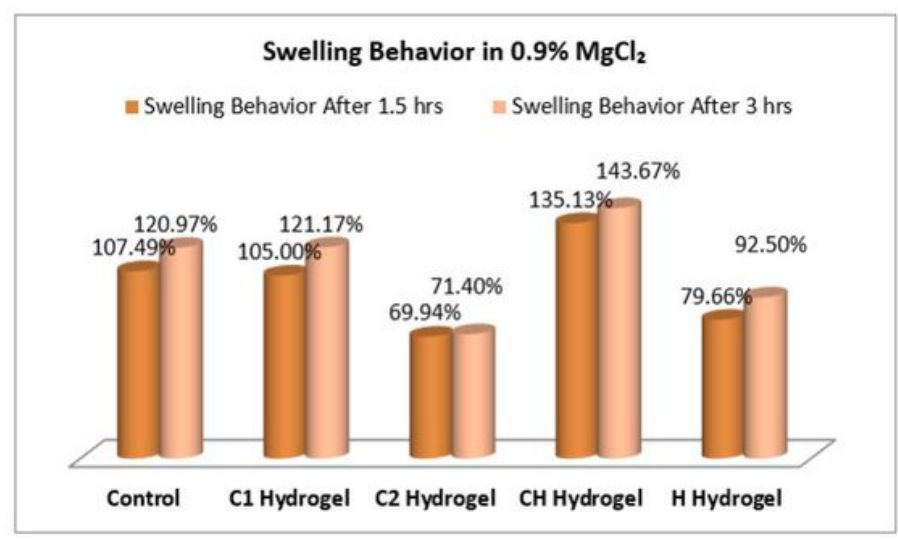

Figure 7- c: Swelling Behavior of hydrogel in $0.9 \% \mathrm{MgCl}_{2}$

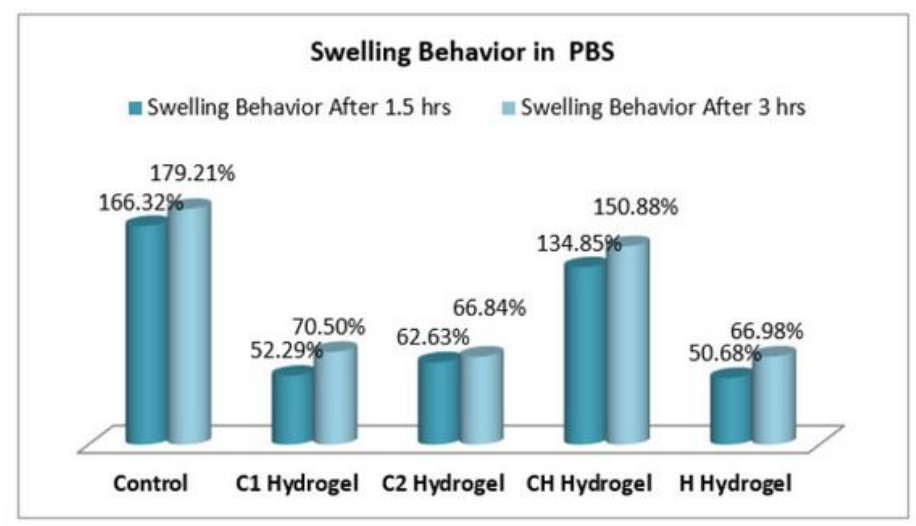

Figure 7- d: Swelling Behavior of hydrogel in PBS

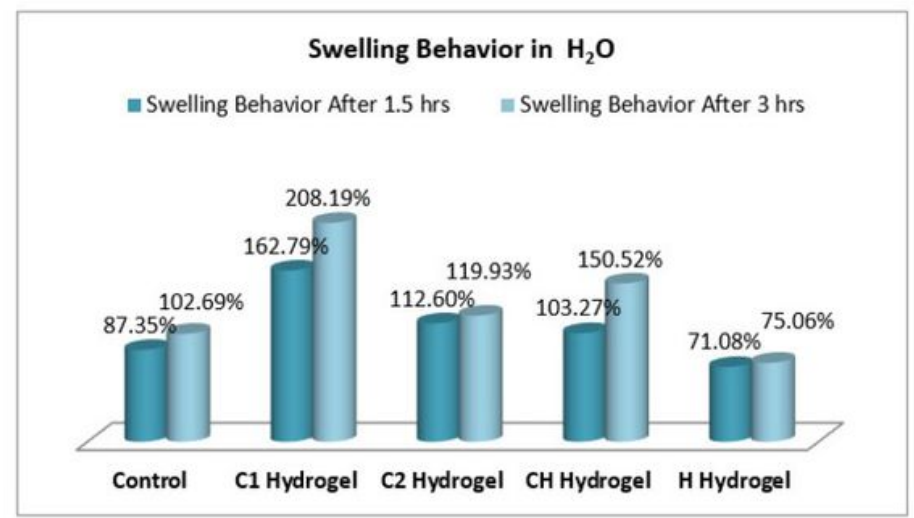

Figure 7- e: Swelling Behavior of hydrogel in $\mathrm{H}_{2} \mathrm{O}$

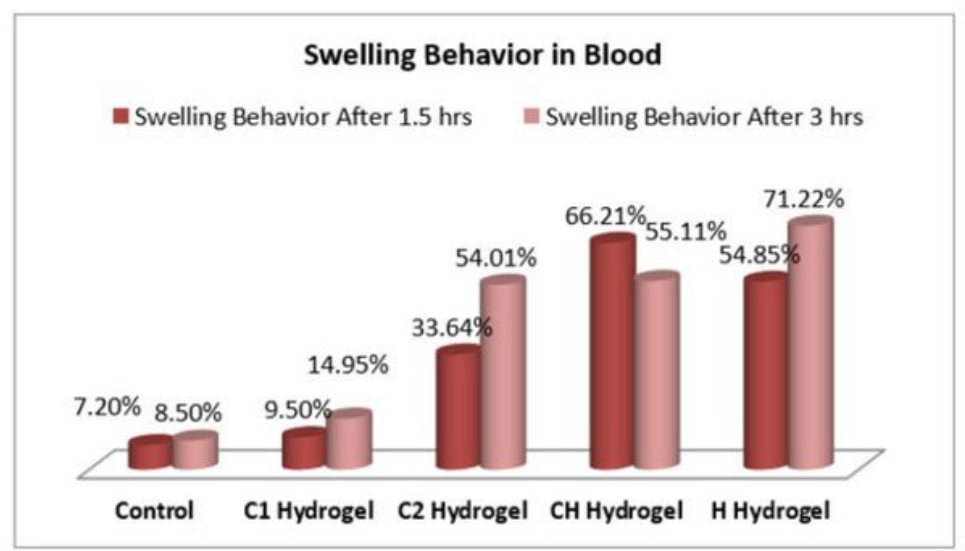

Figure 7- $\mathrm{f}$ : Swelling Behavior of hydrogel in Blood

\section{Figure 7}

\section{Swelling Behavior}



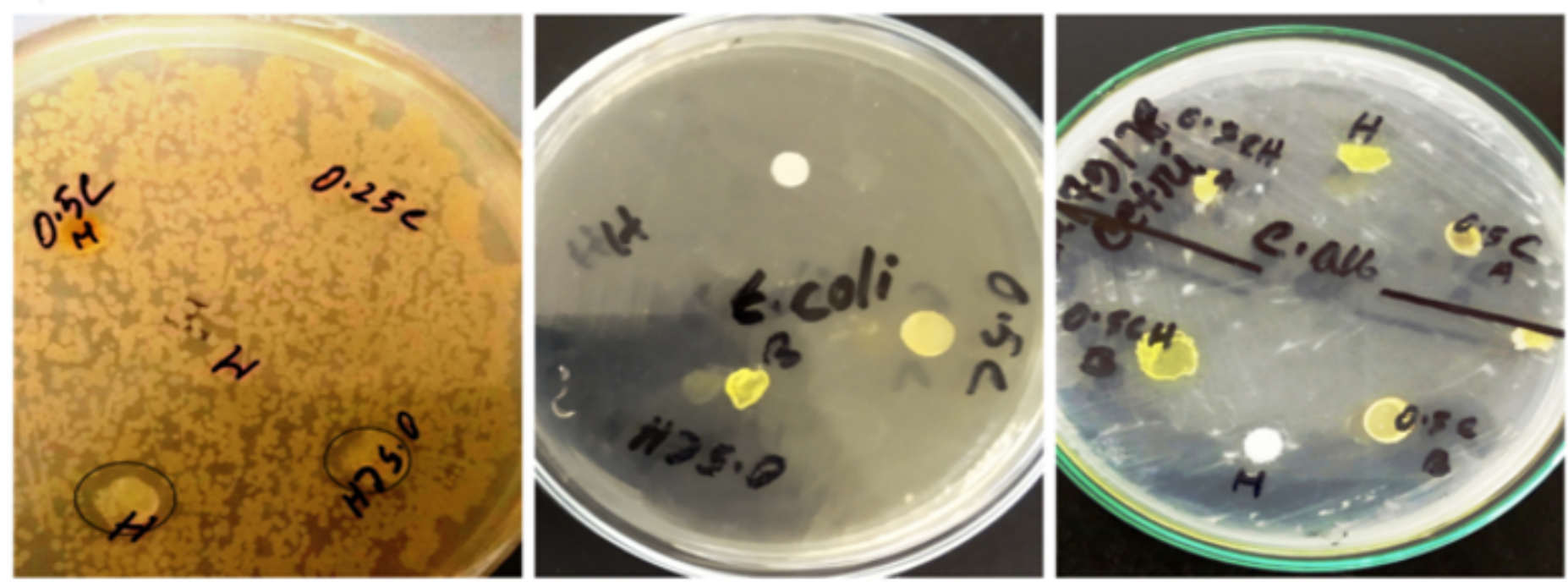

\section{Figure 8}

Antimicrobial activity of hydrogel against S. aureus, E. coli and Candida albicans

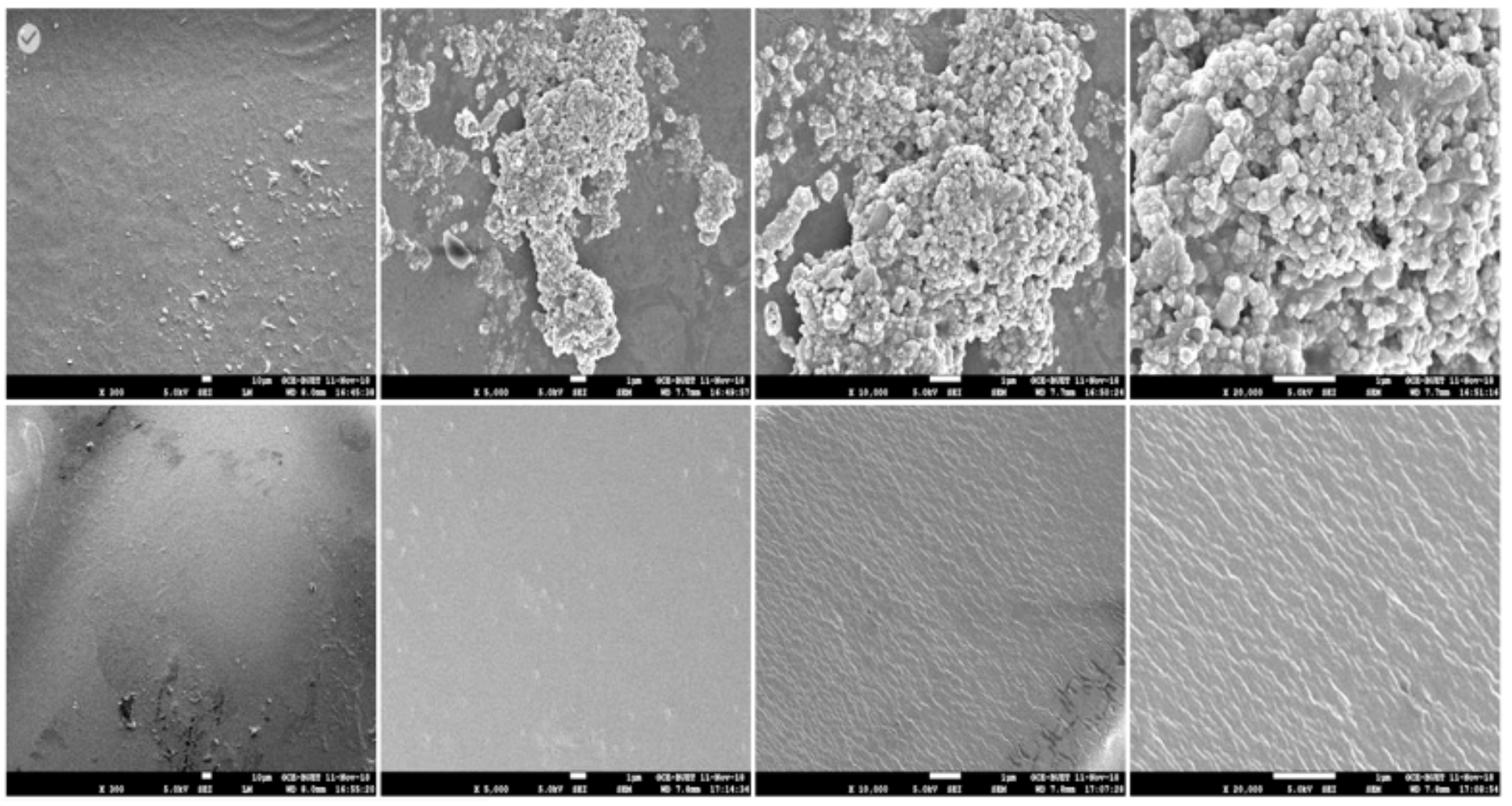

\section{Figure 9}

SEM of Control (Lower) and CH hydrogel (Upper) 


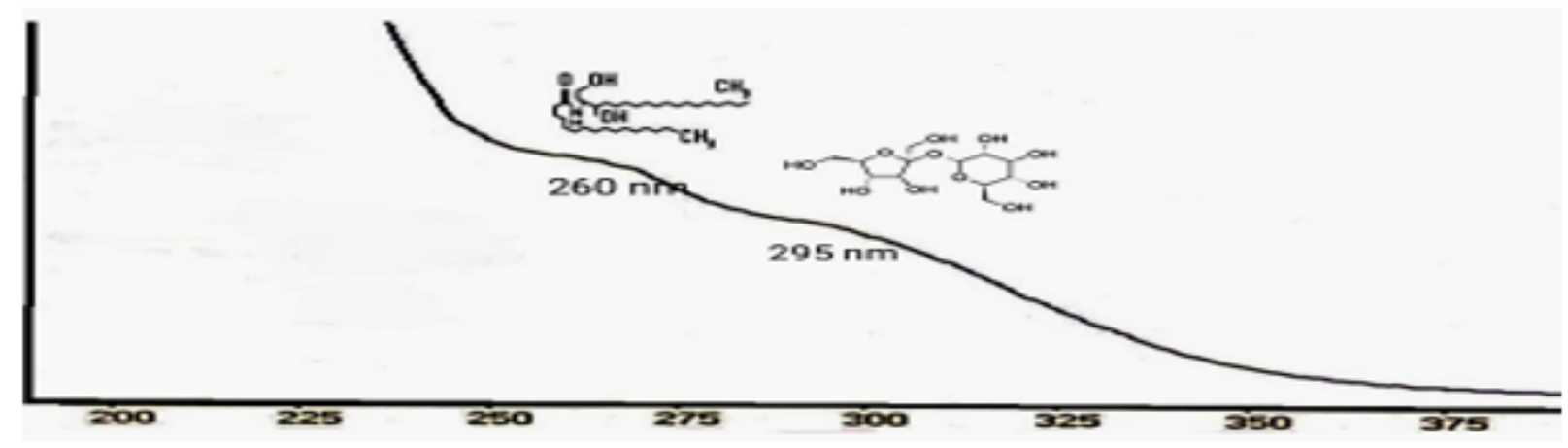

Figure 10: UV Spectroscopy of CH hydrogel

Figure 10

UV Spectroscopy of $\mathrm{CH}$ hydrogel 

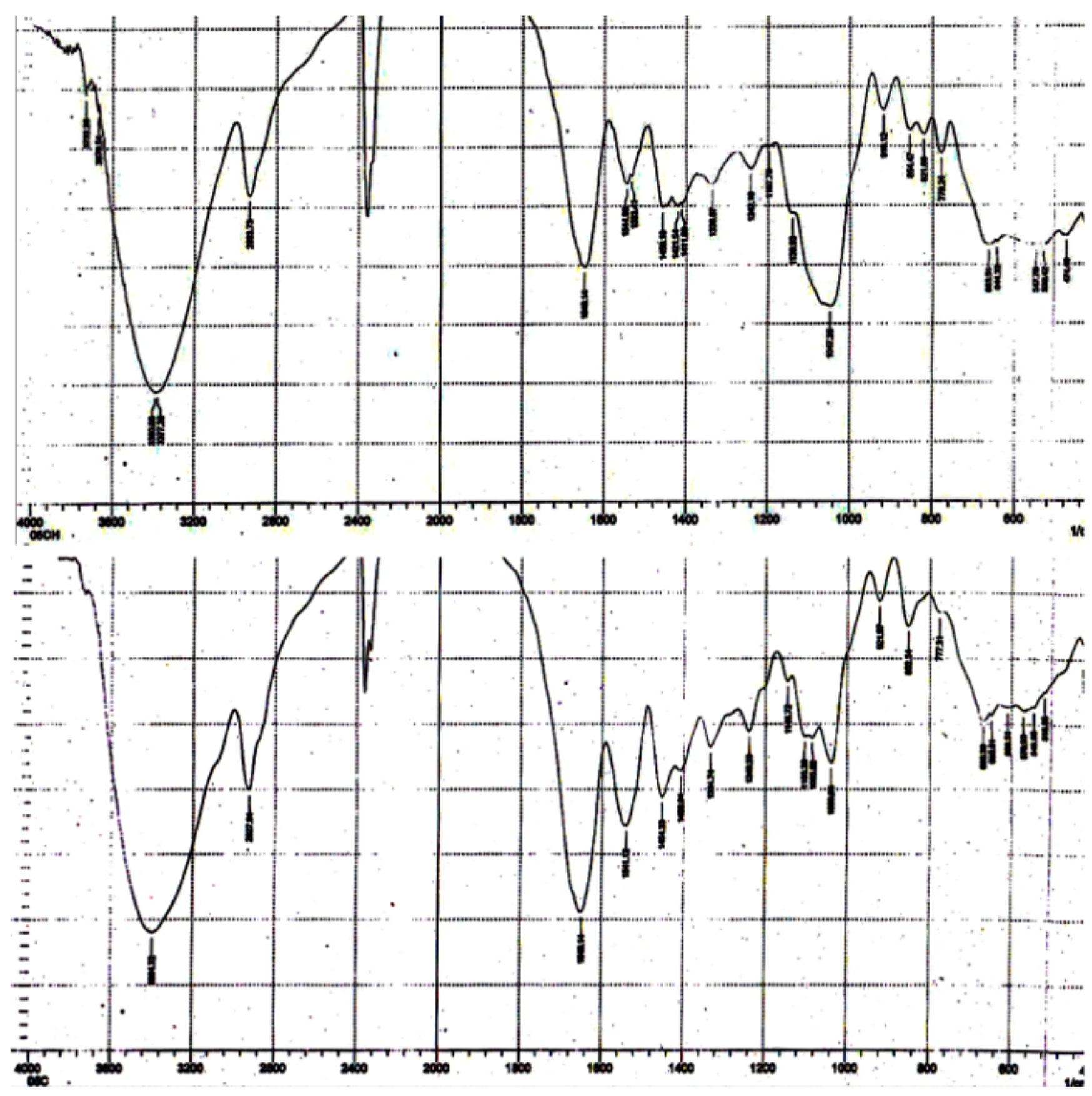

Figure 11a: FTIR of CH hydrogel (Upper), Figure 11b: FTIR of C2 Hydrogel (Lower)

Figure 11

a: FTIR of CH hydrogel (Upper), b: FTIR of C2 Hydrogel (Lower) 

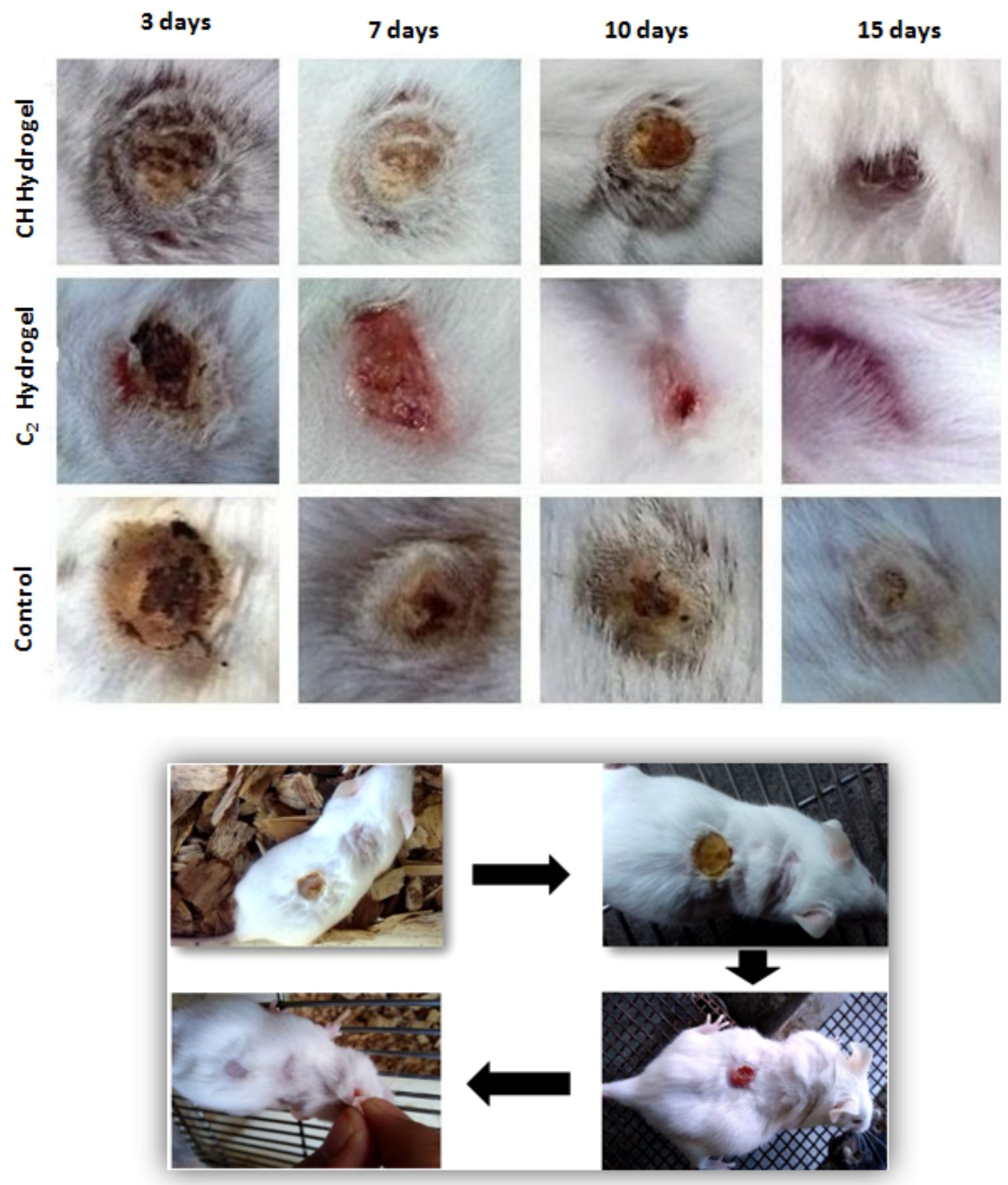

Figure 12: Wound healing in Mice model

Figure 12

Wound healing in Mice model 


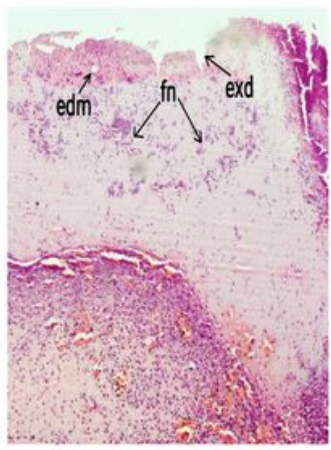

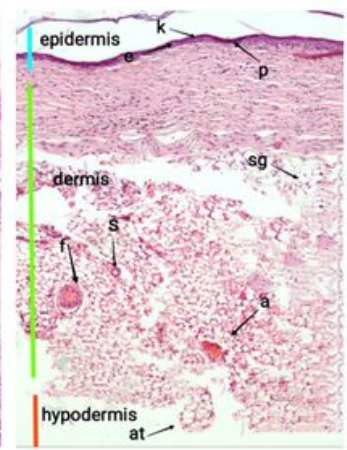

Figure 13 a: image of a control after (no treatment) 18 days, there are presence of edm (edema), fn (fibrinoid necrosis) and exd (serum exudates)

Figure $13 \mathrm{~b}$ : image of a $0.5 \mathrm{CH}$ treated skin, where already formed $k$ (keratinized layer), e (epidermi layer), $\mathrm{p}$ (dermal papillae), sg (sebaceous gland), $\mathrm{f}$ (hair follicles), s (sweat gland), a (arrector pili muscle) and at (adipose tissue)

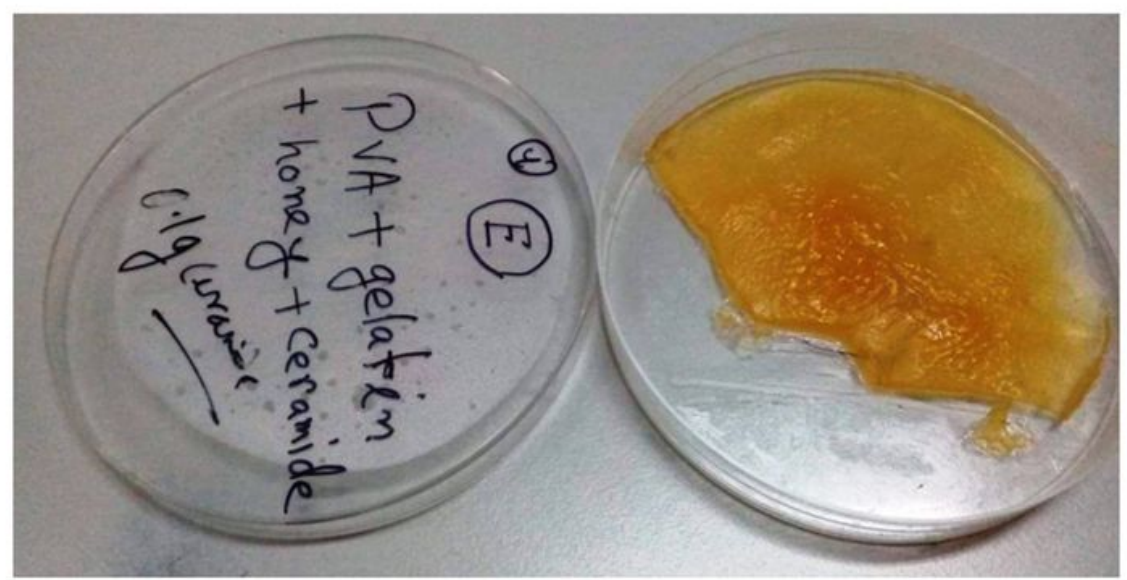

Figure 13: Prepared hydrogel dressings

\section{Figure 13}

a: image of a control after (no treatment) 18 days, there are presence of edm (edema), fn (fibrinoid necrosis) and exd (serum exudates) b: image of a $0.5 \mathrm{CH}$ treated skin, where already formed $k$ (keratinized layer), e (epidermi layer), $p$ (dermal papillae), sg (sebaceous gland), $f$ (hair follicles), s (sweat gland), a (arrector pili muscle) and at (adipose tissue) (Right)Prepared hydrogel dressings

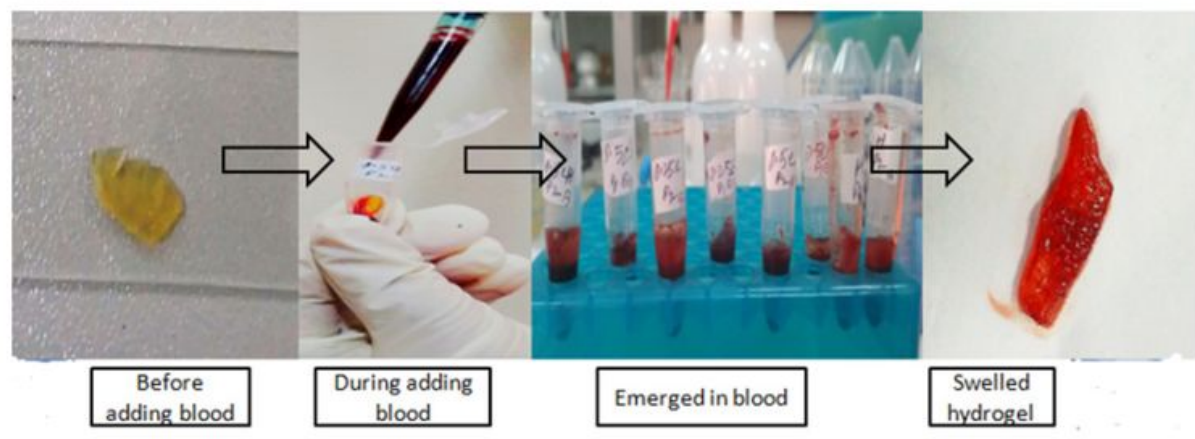

Figure 14: Swelling behavior test in blood

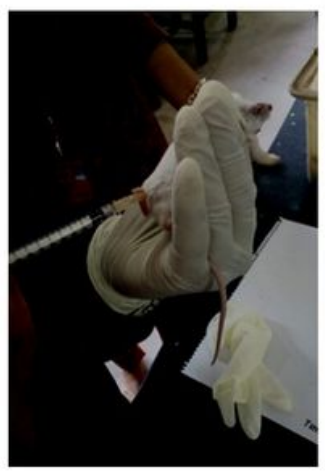

Figure 14: Preparing mice for in vivo wound healing experiment

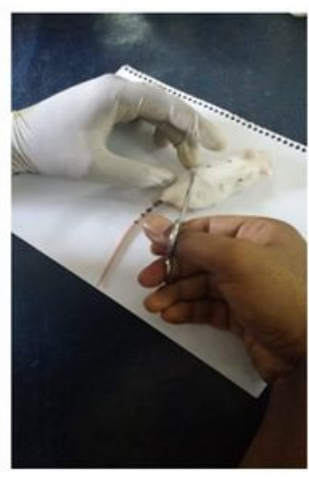

Figure 14

Swelling behavior test in blood (Right) Preparing mice for in vivo wound healing experiment 


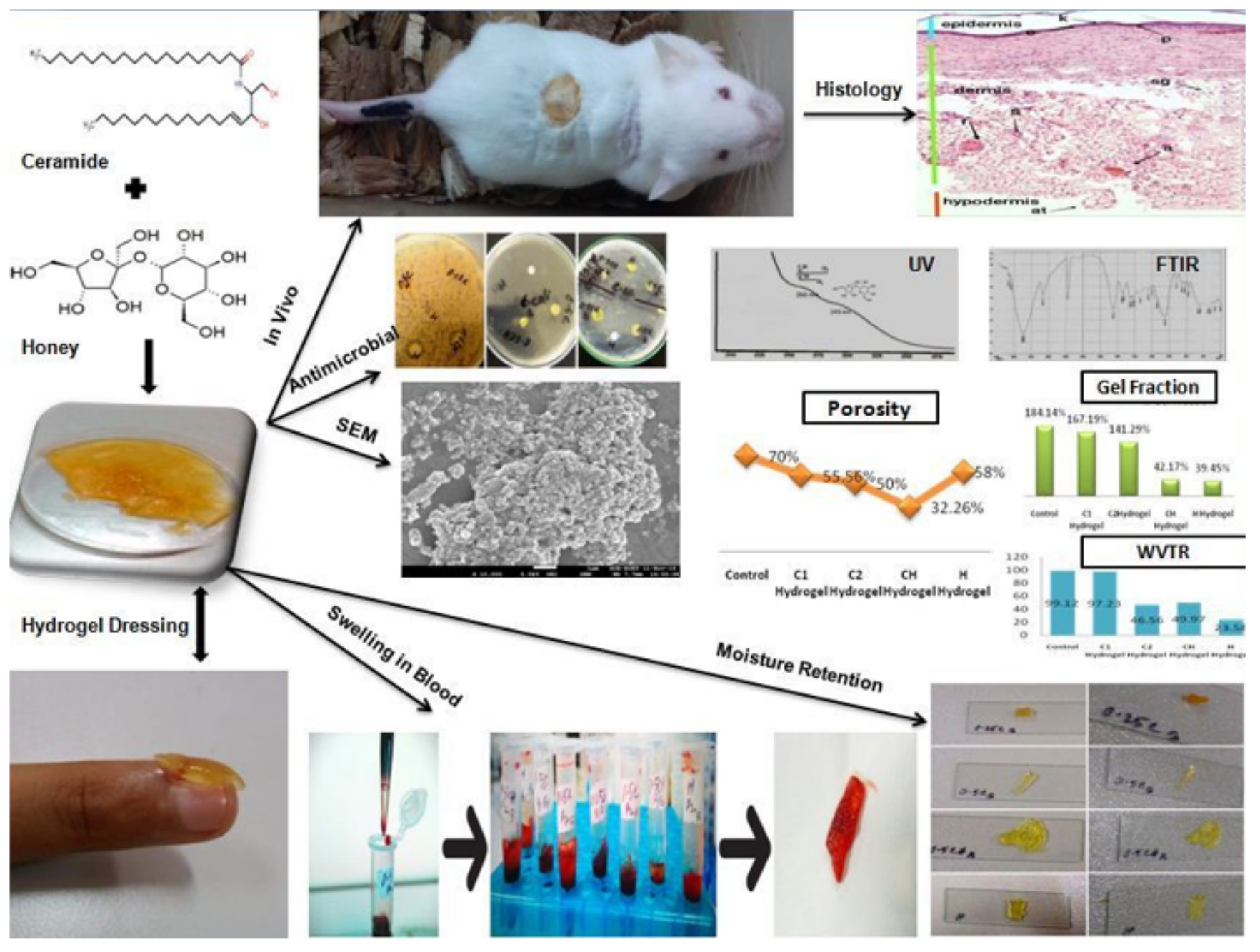

Figure 15: Graphical Abstract

Figure 15

Graphical Abstract 